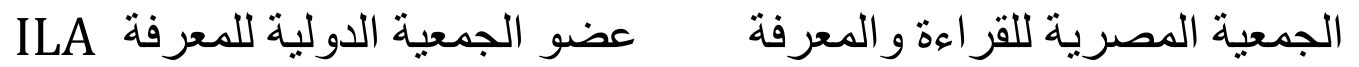

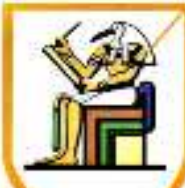

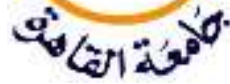

كلية الدراسات العليا للتربية

قسم المناهج وطرق التدريس

\section{تقويم محتوى كتاب التربية الإسلامية للصف الخامس الابتدائي في دولة الكويت في ضوء أبعاد الوعي الديني}

$$
\text { أ / خولة راشد أيوب الدوسري }
$$

إنشراف

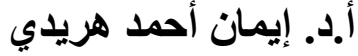

أستاذ المناهج وطرق التدريس التهدي

كلية الاراسات العليا للتربية

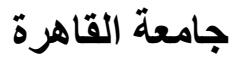

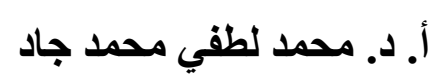

أستاذ ورئيس قسم المناهج وطرق التدريس

كلية الدراسات العليا للتربية

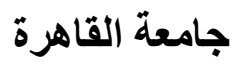




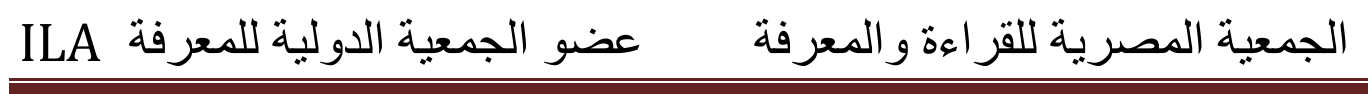




\section{الجمعية المصرية للقر اءة و المعرفة عضو الجمعية الدولية للمعرفة}

تقويم محتوى كتاب التربية الإسلامية للصف الخامس الابتدائي في دولة الكويت في ضوء أبعاد الوعي الايني

مقدمـــة:

يعد منهج التربية الإسلامية من أكثر المناهج التربية أهمية في عالم التربية في العالم الإسلامي-؛ فهو يتناول المبادئ والقيم والمنل العليا التي يشتمل عليها الدين الإسلامي، ويقدمها للمتعلمين في كافة المراحل التعليمية، وهو منهج لا يقتصر على لهى الاهتمام بجانب دون آخر، فهو منهج شامل لجميع جوانب الحياة البشرية، ولجميع جوانب الإنسان، بل ويشمل الاهتمام بأمور الدنبا والآخرة، كما أنَّهَ يعمل على إحداث توازن بين الروح والجسد؛ ولذلك تأتي أهمية كتب التربية الإسلامية، وضرورة نوجيه العناية و الاهتمام الكافيين لها.

ويُعدُّ كتاب التربية الإسلامية أحد الروافد المهمة في تحقيق أهداف تدريس التربية

الإسلامية؛؛ ومن ثنَّ فإنَّهُ يُعدُّ ركيزة أساسية من ركائز العملية التعليمية، فهو يقدم إطارًا محدًا لمقرر التربية الإسلامية كما يهدف إليه واضعو منهج التربية الإسلامية. (مصطفى

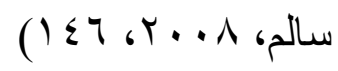

كما أنَّ الكتاب المدرسي يُعدُّ عنصرًا جوهريًا في العملية التعليمية، فهو يمثل الوجه التطبيقي للمنهج، وهو بشكل الوعاء الذي يحتوي المادة التعليمية التي يفترض أنها الأداة التي تستطيع أنْ تجعل المتعلمين قادرين على تحقيق أهداف المنهج. ويحرص خبراء المناهج دائما على بيان العلاقة بين المنهج و الكتاب المدرسي باعتباره وعاء لمحتوى يمثل مكونا مهما من مكونات المناهج، لذلك فدراسة الكتب المدرسية وتحليلها من الدراسات المهمة في ميدان المناهج وطرق التدريس؛ لأن الكتاب المدرسي أداة مهمة من أدوات تنفيذ المنهج، وأداة فاعلة تستخدم مصدرا للتعلم الفردي مئي

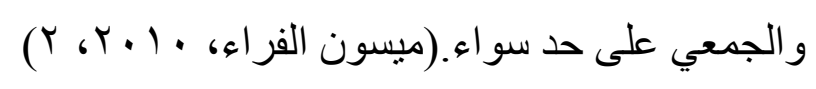
$\varepsilon \cdot V$ 


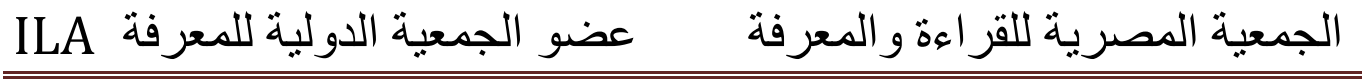

ويأتي في أولوية ما تهدف إلبه مناهج التربية الإسلامية وعي المتعلمين في مختلف

مر احلهم التعليمية بأمور دينهم، وتنمية هذا الوعي لديهه، يما يحقق لهم فهمًا أفضل للدين، ويما يحقق لهم إحداث التوازن الذي يمكنهم من حياة متوازنة في جميع جو انبها. والوعي الديني ذو أهمية كبيرة لجميع المتعلمين، ولا سيما نلاميذ المرحلة الابندائية؛ لأنه يرتبط بنو اح عقلية ووجدانية لدى تلميذ المرحلة الابتدائية، يظهر في صورة سلوكيات أو اتجاهات وممارسات إجر ائية يقوم بها التلميذ الواعي. و الوعي الديني يتضمن معرفة الفرد المسلم بتعاليم الإسلام ومبادئه و أسسه و إدر اكه لها، وتطبيق ذلك من خلال السلوك و الأفعال التي يؤديها الإنسان المسلم، وتكوين مشاعر إيجابية نحو هذه المبادئ والتعاليم لتحقيق استخلافه في الأرض.(سميرة قنديل وآخرون، ( ) $\leq 9 \wedge, 4 \ldots 9$

إن الوعي الديني هو الدرع الواقي ،الذي يحفظ أبناء الأمة من الأخطار ؛ النفسية و الاجتماعية المحدقة بهم، ومن هنا إذا هموا بتحويل المفاهيم الدينية والخلقية إلى عمل وسلوك فانهم سيكونون بمنجاة من أية مؤثرات خارجية، ؛ ذللك لأن تدين الانسان يجب أن يكون نتيجة اقتناع منه، وإيمان ذاتي، وليس حالة من الاسترسال والانسياق الوراثي أو الاجتماعي، كما أن للاين قيما ومبادئ ومقاصد وغايات، فإذا لم يتوفر للإنسان الوعي بذللك، يصبح تدينه مظاهر وممارسات قشرية فارغة، وهذا يستدعي أن ثر اعي عملية تنمبة الوعي إكساب الفرد الخلفية المعرفية، وإكسابه المهار ات اللازمة للسلوك بطريقة مرغوبة ومساعدته في تكوين الميول والاتجاهات الإيجابية نحوها.

ونتيجة لما للوعي الديني من أهمية فقد اهتمت به الكثير من الدراسات، ومنها:

دراسة أحمد الضوي سعد وعبدالمجيد سليمان حمروش(1999، 199) التي أوصت به بضرورة إجراء بحوث ودراسات تستهدف تنمية الوعي الديني في المراحل التعليمية المختلفة. 


\section{الجمعية المصرية للقر اءة والمعرفة عضو الجمعية الدولية للمعرفة}

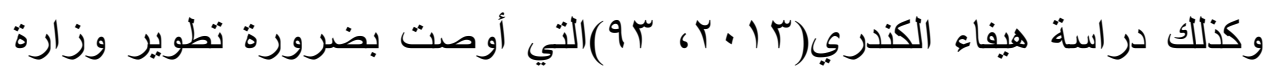
التربية بدولة الكويت لمناهج التربية الإسلامية للتصدي لظاهرة التطرف الفكري؛ من خلال تنمية الوعي الديني.

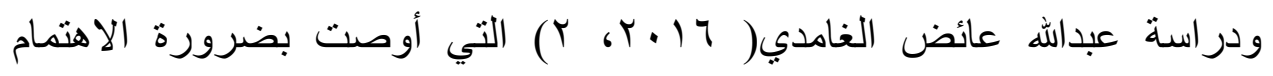
بالوعي الديني لتلاميذ المرحلة الابتدائية، وأن تتضمن المقررات الدراسية ما يسهم في تشكيل الوعي الديني لدى تلاميذ المرحلة الابتدائية.

و إدر اكا لخطورة انخفاض الوعي الديني لدى الأبناء في مر احل العمر المختلفة؛ فقد أوصى مؤتمر "التعصب والتطرف الفكري المقام في كلية الثريعة و الار اسات الإسلامية في دولة الكويت، بضرورة التصدي لجميع الأفكار التي تؤدي الى شيوع السلوكيات الخاطئة، والعمل على إيجاد سبل معالجتها، والذي يعد الوعي الديني الكفيل لنبذ تللك السلوكيات و الممارسات. (مؤتمر التعصب و التطرف الفكري، ( • ب)

وبمر اجعة نتائج الدر اسات السابقة لوحظ أنها اهتمت بعلاج انخفاض الوعي الديني

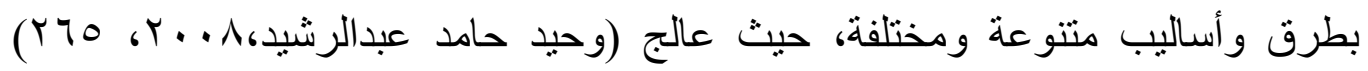
ضعف الوعي الديني لدى التلاميذ من خلال تصميم وحدة مقترحة في التربية الإسلامية لتنمية الوعي الديني لبعض القضايا الحياتية الجنسية لدى طلاب الصف الثالث الثانوي العام، وتعرف فاعليتها في تتمية الوعي الديني، وقد ثبت الأثر الإيجابي للوحدة المقترحة في تنمية الوعي الديني لدى الطلاب .

و عالج (السيد محمد نجم ، ج · . ب) ضعف الوعي الديني من خلال برنامج مقتر ح في التربية الإسلامية لتنمية الوعي الديني لبعض القضايا المحلية و العالمية لدى طلاب المرحلة الثانوية، وقد أظهرت نتائج الدر اسة تقدما ملموسا للمجموعة البحثية في تنمية الوعي الديني لدى الطلبة. 


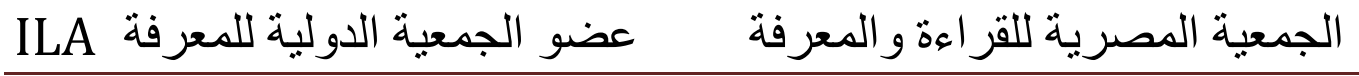

وفي رأي الباحثة فإنَّ كثيرًا من المشاكل التي تحدث في أمتنا الإسلامية ترجع في أسبابها إلى قصور في الوعي الديني لاى أفراد هذه الأمة، ولذلك يتوجب على القائمين على العملية التعليمية بذل مزيد من الجهود في سبيل تحقيق الوعي الديني المطلوب لدى المتعلمين، وفي نفوس النانشئة؛ ليكونوا أفر ادًا صالحين، و لأمتهم وأوطانهم نافعين. ومما ولد الإحساس بمشكلة البحث لدى الباحثة ما يأتي: - - توصيات العديد من الدر اسات و الأبحاث التي أظهرت أنَّ هناك ضعفًا ملحوظًا في الوعي الديني لاى المتعلمين، ومن هذه الدراسات: دراسة لطيفة الكندري، وبدر ملك(9 . . . P، IV) التي بينت أن قلة الوعي الديني من أهم أسباب التطرف

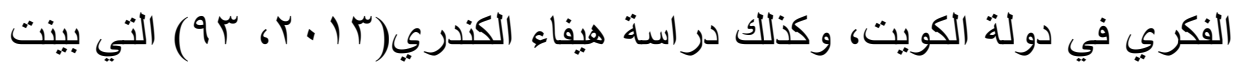
نتائجها ضعف الوعي الديني لدى الثباب في المجتمع الكويتي . - قامت الباحثة بعمل استبانة تتضمن ثلاثة أسئلة للمعلمات عن مدى تمكن تلاميذ المرحلة الابتدائية من الوعي الديني، وزعت على مناطق تعليمية مختلفة( منطقة العاصمة التعليمية، منطقة الفروانية التعليمية، منطقة الجهراء التعليمية، منطقة الأحمدي التعليمية، منطقة حولي التعليمية) وقد اتضح من نتائج إجابات المعلمات وكان عددهم (1) (ع (1)مة، أن تلاميذ المرحلة الابتدائية لديهم ضعف في مستوى الوعي الديني.

- رصدت الباحثة خلال عملها معلمة للتربية الإسلامية في المرحلة الابتدائية وجود كثير من الأفكار و السلوكيات التي تعد مؤشر ا على ضعف الوعي الديني. وترى الباحثة أنَّ أول خطوة لتنمية الوعي الديني لدى تلاميذ المرحلة الابتدائية تتمثل في القيام بمعرفة مدى تو افر أبعاد الوعي الديني في كتب التربية الإسلامية المقررة و المعدول بها حاليًا في مدارسنا، وذلك لا يكون إلا بالقيام بتحليل وتقويم علمي لكتب 


\section{ILA الجمعية المصرية للقراءة والمعرفة عضو الجمعية الدولية للمعرفة}

التربية الإسلامية في المر احل المختلفة في ضوء أبعاد الوعي الديني؛ بما يؤدي إلى معرفة جو انب القوة لتعزيز ها، ومعرفة جو انب الضعف لتلافيها.

ومما سبق يتضح الأهمية التي يحظى بها تقويم كتب التربية الإسلامية في المرحلة الابتدائية؛ وذللك لبيان مدى توافر أبعاد الوعي الديني؛ للبناء عليها في أي عملية تطوير للمنهج، وهو ما يهدف إليه البحث الحالي.

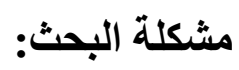

من خلال ما سبق يمكن تحديد مشكلة هذا البحث في حاجة محتوى كتب التربية الإسلامية إلى التقويم الموضوعي لمعرفة مدى توافر أبعاد الوعي الديني فيها، وبما يؤدي إلى معرفة جوانب القوة لتعزيزها، وجوانب القصور لتلافيها، وبما يؤدي إلى الاعتماد

على هذه النتائج في إحداث أي تطوير لهذا المحتوى مستقبلًا. وينبثق من هذه المشكلة السؤ الين البحثيين الآتيين:

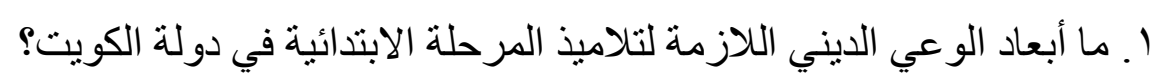
Y. ما مدى تو افر أبعاد الوعي الديني في كتاب التربية الإسلامية للصف الخامس الابتدائي؟

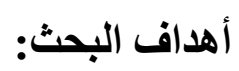
يهدف هذا البحث إلى تقويم محتوى كتاب التربية الإسلامية للصف الخامس الابتدائي في دولة الكويت في ضوء أبعاد الوعي الديني وذللك من خلال: ا ـ تحديد أبعاد الوعي الديني المناسبة لتلاميذ الصف الخامس الابتدائي بدولة الكويت.

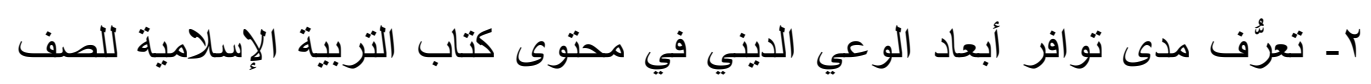
الخامس الابتدائي في دولة الكويت.

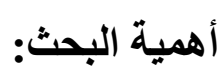
تنبثق أهمية البحث من النواحي الآتية: 


\section{ILA الجمعية المصرية للقراءة والمعرفة عضو الجمعية الدولية للمعرفة}

ا ـ توجيه أنظار العاملين في ميدان التربية والتعليم، ومنهم المعلمون إلى الاهتمام بموضوع أبعاد الوعي الديني اللازمة لتلاميذ المرحلة الابتدائية، وخاصة تلاميذ الصف ولف ولئ الخامس الابتدائي؛ كونه من الموضو عات المهمة. r- إعطاء صورة و اضحة عن مدى تضمين محتوى كتب التربية الإسلامية لأبعاد الوعي الديني، وبيان جو انب القوة لتعزيزها، وجوانب القصور لتلافيها. rـ تساعد مؤلفي كتب التربية الإسلامية ومطوريها في المرحلة الابتدائية في معرفة واقع تضمين هذه الأبعاد، وتطوير ها في ضوء النتائج التي ستسفر عنها. أدوات البحث ومواده التعليمية: - ق قائمة أبعاد الوعي الديني اللازمة لتلاميذ المرحلة الابتدائية بدولة الكويت.

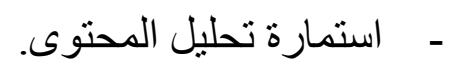

\section{حدود البحث:}

ـ - محتوى كتاب التربية الإسلامية للصف الخامس الابتدائي (الجزئين الأول والثاني). ـ أبعاد الوعي الديني للصف الخامس الابتدائي التي تضمنتها مصفوفة وثثقة المنهج المقرة من وزر اة التربية والتعليم في دولة الكويت للعام (ب ( • rم)، وهي المعدول بها حاليًا. مصطلحاث البحث:

التقويم: يعرف التقويم بأنه عملية منظمة لجمع وتحليل المعلومات بغرض تحديد درجة تحقيق الأهداف التربوية واتخاذ القرارات بشأنها لمعالجة جوانب الضعف، وتوفير النمو

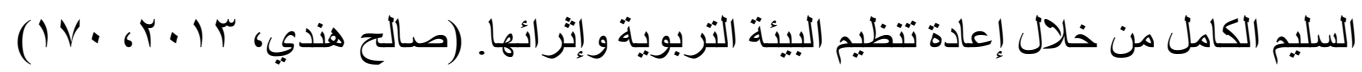
و التقويم في التربية الإسلامية هو عملية تشخيص و علاج ووقاية لمنهج التربية الإسلامية، فالتشخيص يكون بتحديد مواطن القوة والضعف، والعلاج يكون بوضع الحلول المناسبة 


\section{الجمعية المصرية للقر اءة و المعرفة عضو الجمعية الدولية للمعرفة}

لنو احي الضعف و الاستفادة من مو اطن القوة وتدعيمها، و الإبقاء عليها من خلال تحصينها.

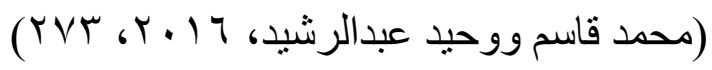

أبعاد الوعي الديني:The Dimensions of Religious Awareness

يعرف الوعي الديني بأنه: توافر المعارف والمعلومات الصحيحة عن الدين

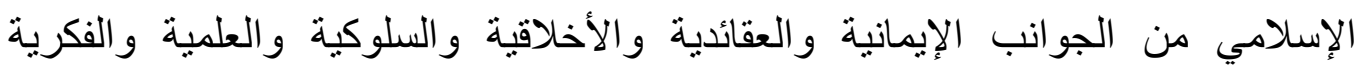

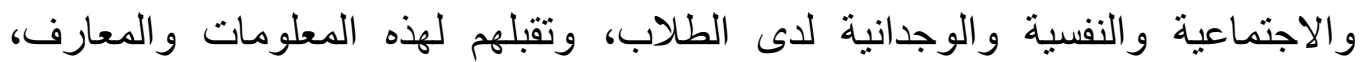

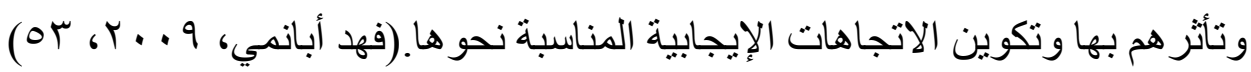
ويمكن تعريف تقويم محتوى كتب التربية الإسلامية في هذالبحث بأنه: عملية

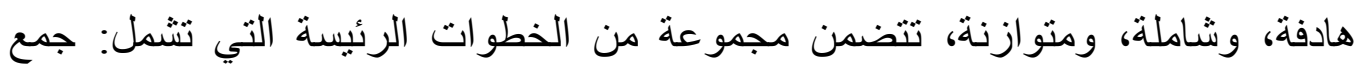
المعلومات الكمية والكيفية، وتحليل المعلومات للوصول إلى إصدار حكم على مدى تو افر أبعاد الوعي الديني في محتوى كتب التربية الإسلامية، وينتهي إلى اتخاذ قرارات مناسبة

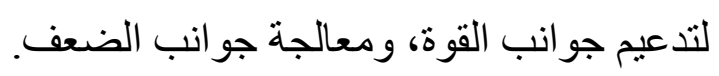
الإطار النظري للبحث: تقويم محتوى كتاب التربية الإسلامية للصف الخامس الابتدائي في ضوء أبعاد الوعي الايني.

تمثلت الخلفية النظرية من خلال الرجوع لأدبيات البحث التربوي، و الاطلاع على البحوث و الدراسات ذات العلاقة حول:

- تقويم المحتوى : مفهومه، أهدافه، مجالاته، محتوى كتب التربية الإسلامية. - - الوعي الديني: مفهومه، أهميته، مجالاته، أبعاده، أسسه تنميته، ومعاييره. 


\section{ILA الجمعية المصرية للقر اءة والمعرفة عضو الجمعية الدولية للمعرفة}

\section{المحور الأول: تقويم المحتوى:}

مفهوم التقويم: ويعرِّفه حسن شحاتة وزينب النجار بأنَّه: أهم أساليب التقويم

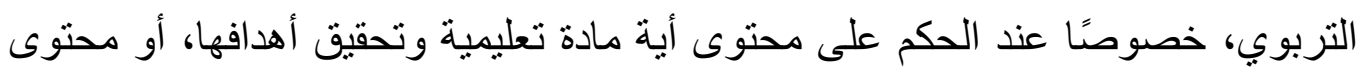
أي منهج در اسي؛ للحكم على مدى جودة هذا المحتوى، ومدى شموله، وتكامله رأسيًا على الى الهي

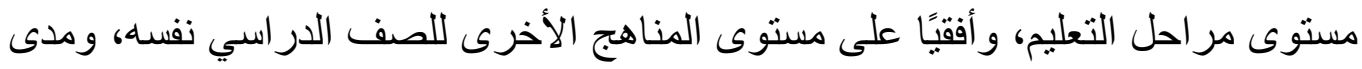
كفايته لتحقيق الأهداف المنوطة به... إلى غير ذلك من المعايير.(حسن شحاتة وزينب

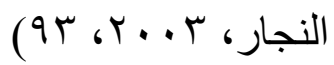

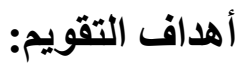

الهذف الأساسي والرئيس من التقويم في منهج التربية الإسلامية هو تطوير العملية

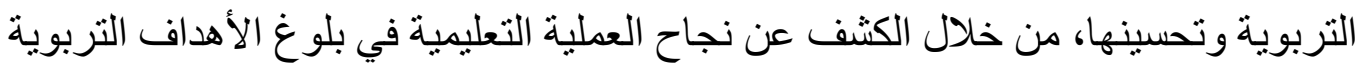
وتحقيقها، ومعرفة جو انب القوة والضعف فيها، و العمل على تعزيز جو انب القوة ومعالجة جو انب الضعف، ويظهر ذلك من خلال الأهداف التالية: تقدير مدى فاعلية منهج التربية الإسلامية بجميع عناصره في تحقيق الأهداف الححددة

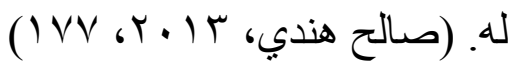

معرفة الفروق الفردية بين التنلاميذ في قدر اتهم واستعداداتهم وميولهم. تعرف مستوى التعلم القبلي للتناميذ وعن مدى استعدادهم المفاهيمي للارس الصفي،

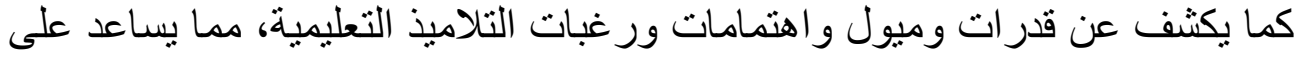
تحديد الأهداف المناسبة، واختيار الخبرات التي تعمل على مر اعاة استعدادات التناميذ

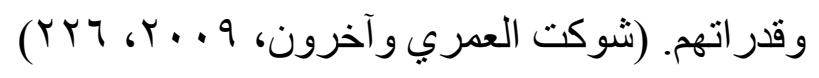

الكثف عن جو انب الضعف في تعلم التلاميذ في مادة التربية الأسلامية، وما يو اجهونه من صعوبات ومشكلات تمهيدا لتحديدها، ومعرفة طبيعتها، وتحديد أسبابها،

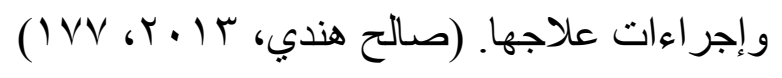




\section{ILA الجمعية المصرية للقر اءة والمعرفة عضو الجمعية الدولية للمعرفة}

تحديد قيمة الأهداف التعليمية، ومدى مر اعاتها لخصائص التلميذ، وحاجات المجتمع،

وطبيعة المادة التعليمية و المستحدثات المعرفية.

تحديد الصعوبات التي تواجه تتفيذ المنهج، ومعرفة الظروف التي تعوق العملية

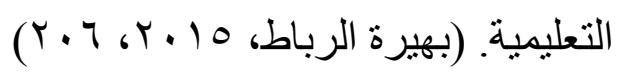

مجالات التقويم لعناصر منهج التربية الإسلامية

تتعدد مجالات التقويم التي يمكن توظيفها في التربية الإسلامية، لتشتمل على تقويم

جوانب العملية التعليمية كافة، تلك المجالات يمكن تلخيصها على النحو التالي:

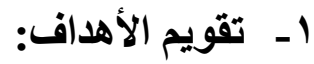

ومن معايير تقويمها:

تترجم طبيعة منهج التربية الإسلامية وفلسفته و أسسه.

تعكس طبيعة الدين الإسلامي عقيدة و عباده ونظاما شاملاً للحياة.

تؤكد على أهمية مصادر المعرفة في الاسلام وبخاصة القرآن الكريم والسنة النبوية

$$
\text { والاجتهاد. }
$$

تتصف بالتحديد و الوضوح في صباغتها، وبالإجر ائية بحيث تكون قابلة للملاحظة

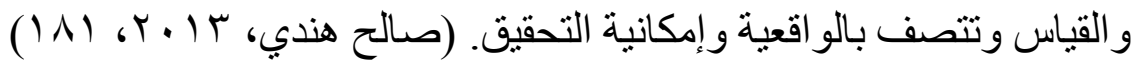

تشمل جو انب شخصية المتعلم كافة جسيماً و عقلياً وروحياً واجتماعيا ومهارياً.

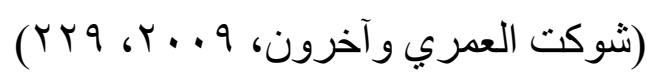

أن تكون شاملة بحث تتضمن المجالات الثلاثة المعرفية والوجدانية و المهارية.

$$
\text { ومن مع تقويم المحتوى: }
$$

يترجم اهداف تدريس منهج التربية الإسلامية. 


\section{ILA الجمعية المصرية للقر اءة والمعرفة عضو الجمعية الدولية للمعرفة}

يقدم على شكل موضو عات متر ابطة يركز كل منها على موضوع أو مفهوم معين تنظم فيه الخبرات التعليمية بشكل متتابع ومستمر في الصفوف والمراحل

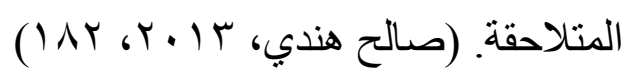

يقدم مادة علمية صحيحة ومتفق عليها، وتعالج قضايا حديثة معاصر يسنخدم لغة مناسبة لمستوى التلاميذ، ومناسبته للزمن المخصص له ـ (شوكت

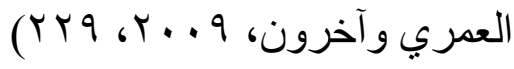

$$
\begin{aligned}
& \text { يتم بالتوازن بين الثمول و العمق. }
\end{aligned}
$$

يعكس حاجات التلاميذ ومشكلاتهم وميولهم، وير اعي المحتوى الخلفية المعرفية

$$
\begin{aligned}
& \text { لتلاميذ. (فتحي يونس و آخرون، } 7 \text { ( ب ك، ع (0) } \\
& \text { r- تقويم استراتيجيات التدريس } \\
& \text { ومن معايير تقويمها: }
\end{aligned}
$$

ارتباطها بالأهداف التعليمية لمنهاج التربية الإسلامية

تعتمد مداخل متنو عة مثل بناء المواقف التدريسية على الأحداث الجارية، أو التعلم من المصادر المختصة في البيئة أو التعلم بالقدوة و التعلم بالممارسة. تؤكد على تحويل الأفكار و المفاهيم إلى سلوك يمارسه التلاميذ. تناسب طبيعة موضو عات التربية الإسلامية.

تناسب مستوى التلاميذ وقدراتهم واهتماماتهم، وترعي الفروق الفردية بينهم.

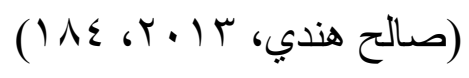

تدرب التلاميذ على البحث و الاكتشاف، والاستقصاء وحل المشكلات، وتتيح فرصا متعددة لمشاركة التلاميذ في مواقف التعليم والتعلم، بحيث تنمي التفكير التأملي

$$
\text { و الإبداعي لدى التلاميذ. (فتحي يونس وآخرون، } 17 \text { • ب، ع (0) }
$$

تهنم بالجانب العلمي والتطبيقي، حيث تؤكد على تحويل الأفكار والمفاهيم إلى سلوك بماسه التلاميذ. 


\section{ILA الجمعية المصرية للقر اعة والمعرفة عضو الجمعية الدولية للمعرفة}

تر اعي الوقت المخصص للتربية الإسلامية في الخطة الدر اسية.

تر اعي إثـارة دافعية التلاميذ، وأن توجه لأكثر من حاسة من جواسهم. (شوكت

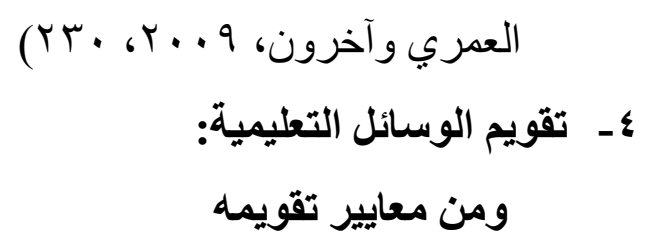

ترتبط بالأهداف التعليمية لموضو عات التربية الإسلامية.

تساعد على تنمية الملاحظة والتأمل والقدرة على التفكير لدى التلاميذ. (صالح

$$
\text { هندي، س (V) }
$$

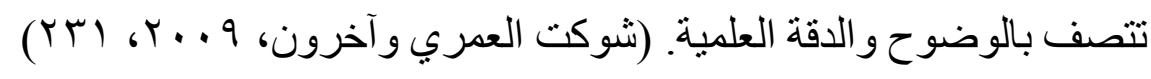

تحتوي الوسبلة على معلومات صحيحة وسليمة، وتحقق الهذف المرسوم لها.

أن تكون الوسيلة واضحة ودقيقة، وشيقة، وسهلة الاستخدام و التوظيف. (فتحي

$$
\begin{aligned}
& \text { يونس و آخرون، } 7 \text { ( • Y، } 7 \text { (0) } \\
& \text { 0ـ تقويم الأنشطة التعليمية: } \\
& \text { ومن معايير تقويمها: }
\end{aligned}
$$

ترتبط بالأهداف التعليمية لموضو عات التربية الإسلامية، وتعمل على تحقيقها.

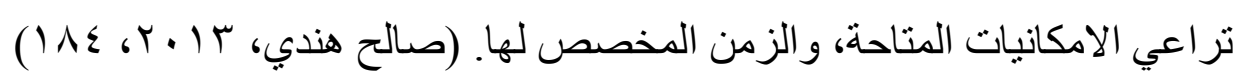
تر اعي مبدأ التنوع، ومبدأ التكامل فيما بينها. تناسب مستوى نضج التلاميذ، وتراعي الفروق الفردية بينهم. (فتحي يونس

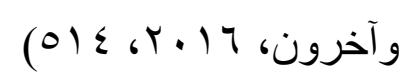

تشنمل على أنشطة دينية غير صفية، ترتبط بالبيئة و المجتمع

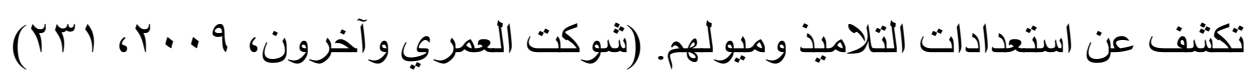

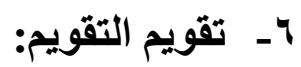




\section{ILA الجمعية المصرية للقر اءة والمعرفة عضو الجمعية الدولية للمعرفة}

\section{ومن معايير تقويمه:}

يرتبط بأهداف منهج التربية الإسلامية، ويشمل المجالات المعرفية والوجدانية

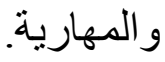

ير اعي النشاط الديني والجانب التطبيقي العبادي من خلال أداء العبادات والمو اقف

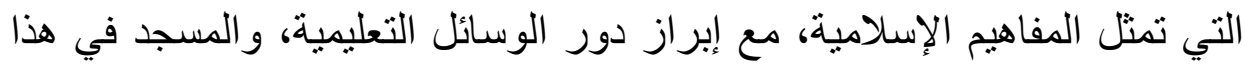

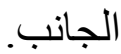

تتصف عناصره الابداعية بحيث ينخطى التعليم الفردي، وتعلم المجموعة،

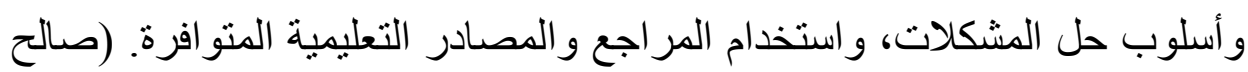

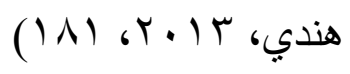

$$
\text { تتصف أدو اته بالصدق و الثبات و الموضو عية. }
$$

يلائم مستويات الطلبة أو يراعى الفروق الفردية بينهم. (شوكت العمري وآخرون،

$$
\text { (r T } 9 \text { ، r... } 9
$$

أن تتحقق في أساليب التقويم مبادئ الثمول والتتوع و التكامل

$$
\text { أن يتحقق في التقويم مبدأ الاستمر ارية. }
$$

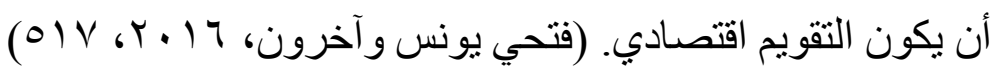

\section{محتوى كتاب التربية الإسلامية للصف الخامس الابتدائي في دولة الكويت:}

يشتمل كتاب التربية الإسلامية للصف الخامس الابتدائي على كتابين، وهما الجزء الأول للفصل الدراسي الأول، والجزء الثاني للفصل الدراسي الثاني، ويشتمل كل جزء الأساء على ستة فروع، وهي: (العقيدة، وعلوم القرآن، والحديث الثريف، والسيرة النبوية، و الفقه، والتهذيب)، ويضم كل فرع وفي كل جزء ثلاثة دروس، وبذللك يتضمن كل

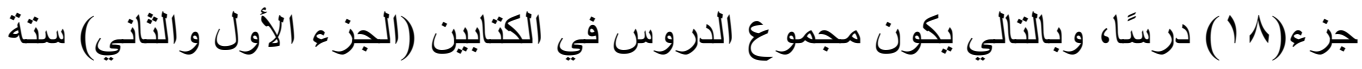

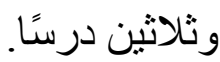




\section{ILA الجمعية المصرية للقر اءة والمعرفة عضو الجمعية الدولية للمعرفة}

\section{المحور الثاني: الوعي اللاني: تعريف الوعي الديني:}

يمكن تعريف الوعي الديني بأنه ما يتكون لاى التلميذ من أفكار ووجهات نظر النافي

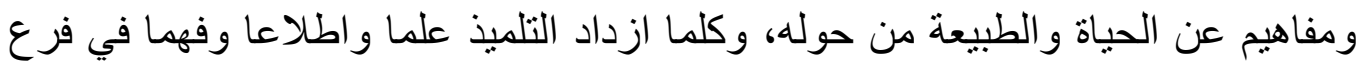

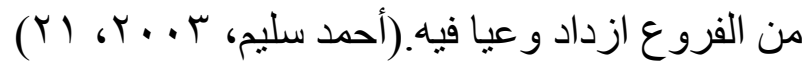

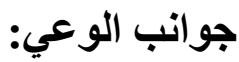

يتضمن الوعي ثلاثة جو انب: الجانب المعرفي المتمتل في الحفظ و الفهم والإدر الك، و الجانب السلوكي المتمثل في التطبيق العملي لما تم حفظه وفهمه و إدراكه، و الجانب

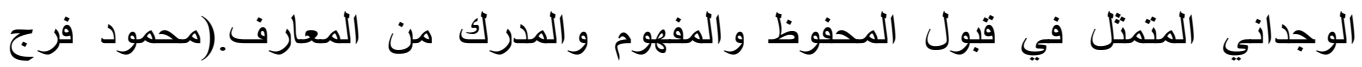

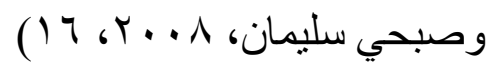
و ولى ذلك فإن الوعي يؤسس على ثلاثة جوانب: الجانب المعرفي (عقله)، و الجانب الوجداني(إيمانا به)، والجانب التطبيقي(عملا بمقتضاه)أما من حفظ ألفاظه وضيع

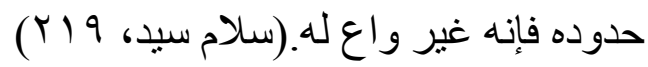

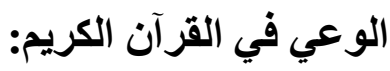

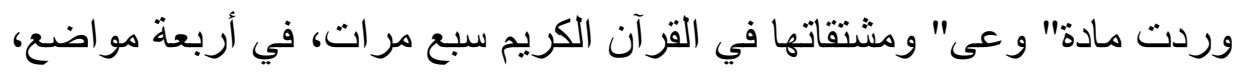
بعضها يدور حول الحفظ والفهم والإدراك، كما في قوله تعالى " وتعيها أذن واعية" (الحاقة: r (1)، أب تحفظها أذن وصفت بأنها تحفظ ما يجب حفظه، بتذكره و إنثاعته و التفكير فيه و العمل بمقتضاه، ومنها قوله تعالى" قال ابن عباس و اعية: سامعة حافظة، ومنها قوله لهابله

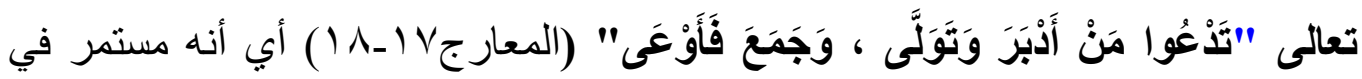

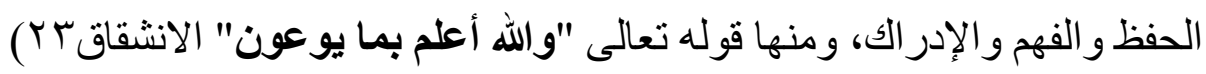

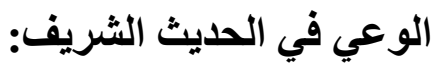




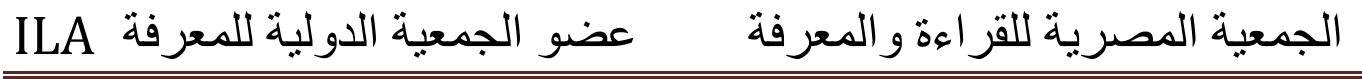

ورد لفظ الوعي في أحاديث كثيرة منها ما جاء في حديث أبي أمامه، عن رسول

الله صلى الله عليه وسلم أنه قال" لا يعذب الله قلبا وعى القرآن" قال ابن الأثثر : أي عقله وحفظه إيمانا به و عملا، فأما من حفظ ألفاظه وضيع حدوده فإنه غير واع له، وفي قول رسول الله صلى الله عليه وسلم " نضر الله امر أسمع مقالتي فو عاها" و عاها بعني: حفظها، (جمال بن منظور، ـو 190) وقوله صلى الله عليه وسلم،" فرب مبلغ أوعى من سامع "

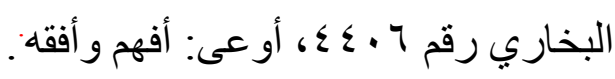
أهمية الوعي الديني:

يعد الوعي الديني ذا أهمية كبرى لتلاميذ المرحلة الابتدائية؛ لأنه يرتبط بنواح عقلية ووجدانية لدى تلميذ المرحلة الابتدائية، يظهر في صورة اتجاهات أو سلوكيات

$$
\text { وممارسات إجر ائية يقوم بها التلميذ الو اعي. }
$$

و وتتضح أهمية الوعي الديني من خلال النقاط التالية:

ا. الوعي الديني يعمل على تعميق إيمان التلميذ بالله تعالى، واعتقاده بوجوده، وممارسته لسلوكيات طبقا لهذا الإيمان، وتلك العقيدة، مر اعيا تعاليم الدين في دينه

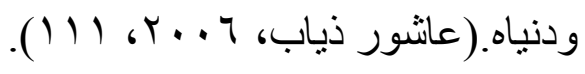

r. الوعي الديني مصدر خصب لإشباع الميول والدوافع النفسية لدى التلميذ، كالمشاركة الوجدانية، والتقليد و المحاكاة والايحاء، والانتماء الاجتماعي، وبذلك فهو يقوي نزعة التلميذ للتكامل والتعاون مع غيره، مما يستخل لخيره وخير

$$
\text { مجتمعه. (عبدالحمبد الزنتاني، سو } 99 \text { (1)، (ب) }
$$

r. يسهم الوعي الديني في تكوين عاطفة دينية تسمى الوازع الديني، تكون بمثابة الرقيب الذاتي الداخلي، والذي يستقتيه التلميذ فيما يجد من أمور وقضايا، و عندما يتكون لدى التلميذ هذا الوازع فإنه لا يحتاج إلى رقيب خارجي يأمره بالمعروف، لئه

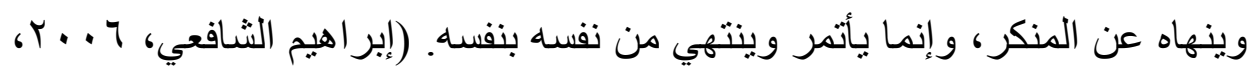




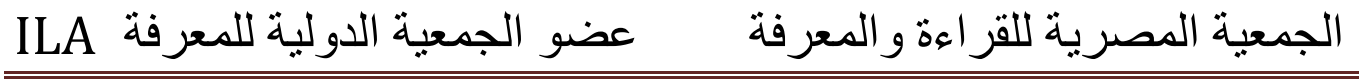

؛. يقوي الوعي الديني إرادة التلميذ، لأن الدين مصدر القيم الخلقية ومصدر القيم العليا، ومن ثم إن لم يتوفر لدى الفرد الوعي الكامل بالدين لن تتحقق لله هذه

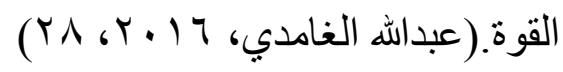

•. يساعد الوعي الديني على تعميق القيم والاتجاهات الدينية في نفوس الناشئة، مما يؤدي إلى ترجمتها إلى سلوك داخل المدرسة وخارجها.(عبدالتواب عبداللاده T. الوعي الديني يمنح التلميذ القرة على مواجهة تحديات العصر..(عبداله الغامدي،

V. يساعد التلميذ على تحقيق السلوك الديني الصحيح، لأن الوعي الديني يجعل الفرد يشعر بأن الله يراقبه، ويحس بأن الله يراه، ومطلع عليه في كل سلوكياته.(أحمد

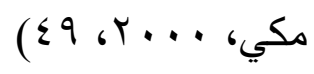

وترى الباحثة أن الوعي الديني ضرورة حتمية لتلاميذ المرحلة الابتدائية حتى ينشأ التلاميذ على معايير تسهم في تكوين التلميذ المؤمن المستقيم، الملتزم ذاتيا، الذي ير اقب اله عز وجل في كل أقو اله، وما يقوم به من عبادات، وطاعات، و أعمال. أسس تنمية الوعي الايني: ا. مر اعاة المستوى العقلي للتلميذ، من حيث معدل النمو والنضج، ومن حيث ذكائه و واستعداداته وقدراته وملكاته العقلية، واختيار الأسلوب الناجح في تعليمه وتوجيهه

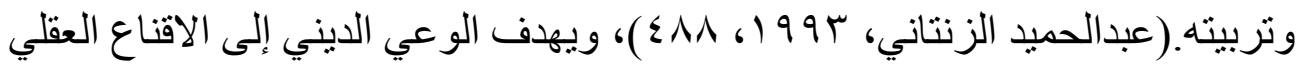
للعقيدة الإسلامية بأسلوب عقلي ووجداني يؤدي إلى السلوك القويم.( محمد

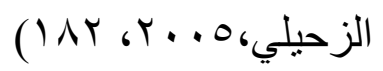

Y. مر اعاة طاقة التلميذ ومقدرته، وجعل العملية التعليمية ساره ومشوقة له، واعطاؤه القسط الو افر من الر احة العقلية والجسدية، وتجنيبه الإرهاق و المشقة في عملية التعليم،

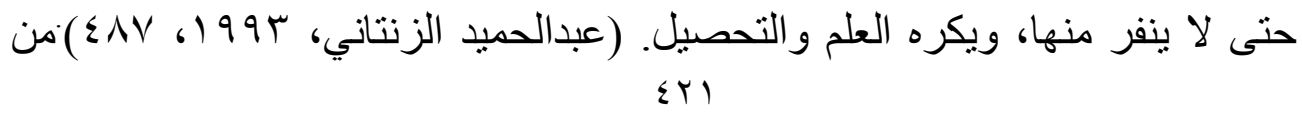




\section{الجمعية المصرية للقر اعة والمعرفة عضو الجمعية الدولية للمعرفة}

خلال الأنشطة الدينية الدختلفة، والتثثيليات والبرامج الإذاعية والرحلات.(هدى

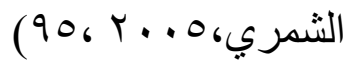

r. مراعاة ميول التلميذ ومواهبه، وهواياته وحاجاته، ودوافعه الفطرية، مع توجيهه

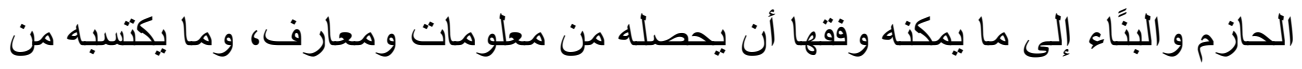

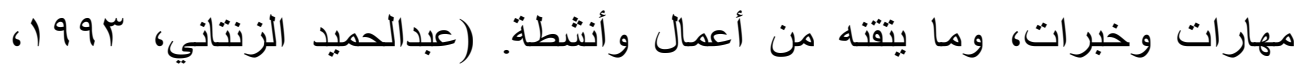

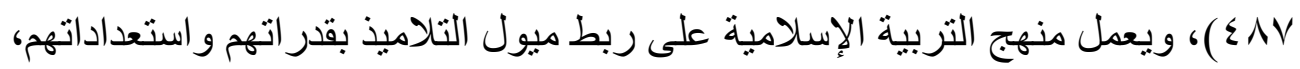

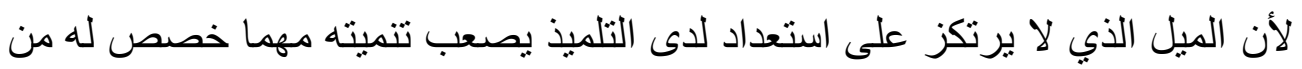

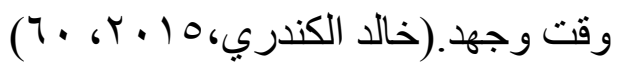
ع. مراعاة الفروق الفردية بين التلاميذ، وتفاوت خطوهم من الذكاء والقدرات، و الاستعدادات العقلية، وتمايزهم في الخصائص الوجدانية والطاقات الجسمانية، مما لهان

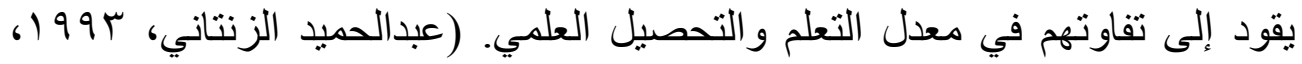

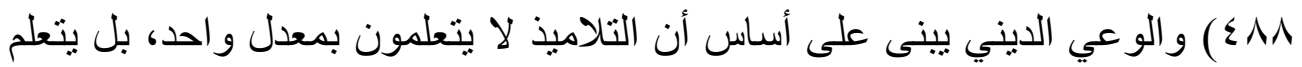

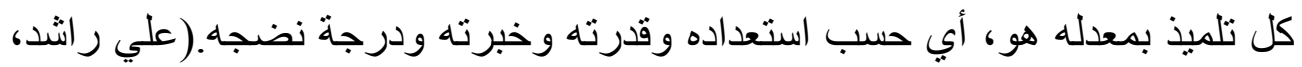
( r人 6 199 ○. مر اعاة إتاحة الفرصة للممارسة العملية، وتهيئة سبل التجربة و المحاولة والخطأ، مع التوجيه السديد، و الحزم الرشيد، حتى يشارك المتعلم مشاركة ذاتية مباثرة في عملية

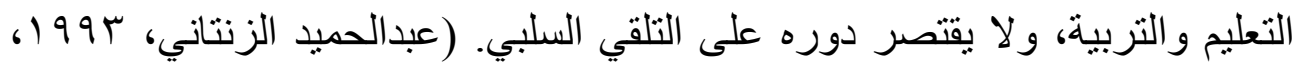
كAN1)، ويقوم الوعي الديني بتحويل المعارف و الخبرات الدينية إلى عادات سلوكية،

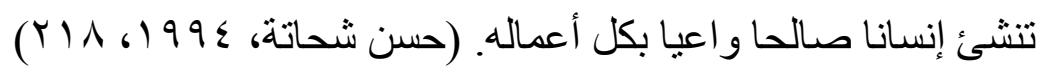
T. استخدام استراتيجيات تدريس متنوعة تثري منهج التربية الإسلامية وتنمي الوعي الديني لدى التلاميذ، وتتناسب موضو عاتها و أهدافها ومستوى تلميذ المرحلة الابتدائية

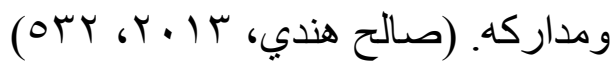




\section{ILA الجمعية المصرية للقراءة والمعرفة عضو الجمعية الدولية للمعرفة}

V. مر اعاة تشجيع المتعلم على إعمال تفكيره، والتبصر، حتى يتمكن بنفسه من الفهم و الادر الك المباثر للحقائق و المعلومات والمعارف، بدل اعتماده على الحفظ الآلي دون

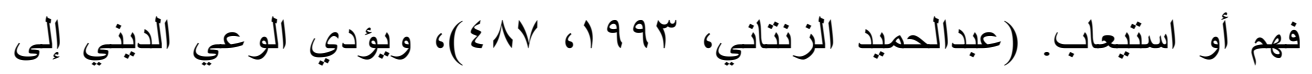

الاقتناع الفكري بدل التقليد الأعمى. (وضحة السويدي، 911 (، بـ؛)

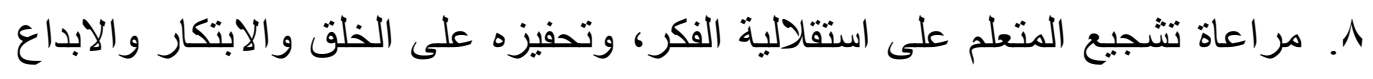
والتجديد، حتى يؤتي الوعي الديني ثماره في إعداد العقول الخلاقة المبدعة الواعية.

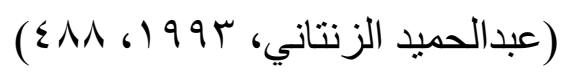

وترى الباحثة ضرورة مر اعاة هذه الأسس في المرحلة الابتدائية، لما لها من أهمية في إيصال التلاميذ إلى النضج العقلي، والاقتناع الفكري، و الميل الديني، مما يؤدي إلى تنمية الوعي الديني. معايير الوعي الديني:

يقصد بمعايير الوعي الديني العلامات المحددة للوعي من حيث ما يجب أن تتوافر في أبعاده، وتصاغ تللك العلاقة في عبار ات و اضحة ومحددة، وتخص كل بعد من أبعاد الوعي الديني(البعد المعرفي، البعد الوجداني، البعد السلوكي)، وسنتطرق إلى ذكر هذه المعايير، دون الإشارة إلى المؤشر ات التي تندرج في إطار ها.

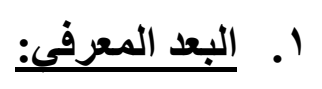

يتضمن البعد المعرفي تزويد التلاميذ بالمعرفة الدينية للعقيدة السليمة، بحيث يتكون لديهم قاعدة علمية نظرية للعقيدة الإسلامية، نشبع الحاجة لديهم إلى المعرفة الدينية بما يدور في خيالهم من أفكار تجاه دينهم، وتصحيح المفاهيم الدينية الخاطئة لديهم، وامدادهم بالمفاهيم الصحيحة للاين الإسلامي. وتزويد التلاميذ بالمعلومات الدينية التي تتصل بالعبادات والمعاملات وغيرها، ليتسنى لهم ممارسة تلك العبادات، و أدائها بالطريقة

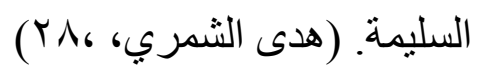




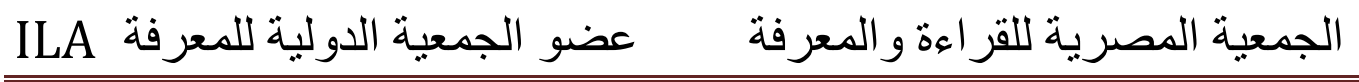

\section{ومن معايير البعد المعرفي ما يلي:}

ا. معرفة أركان العقيدة الإسلامية على أساس من الفهم والاقتناع. (مصطفى

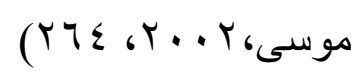

r. ترسيخ عقيدة التوحيد بما يتناسب مع تلاميذ المرحلة الابتدائية، بحيث يحل الإيمان

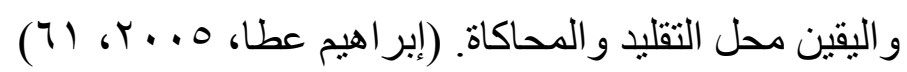
r. تقديم المفاهيم الدينية التي تنمي مدارك التلاميذ، وتجيب عن تساؤلاتهم، وما يدور في ري عقو لهم، وإحاطة المفاهيم المجردة منها بالعديد من الأمثلة التي تعمل على توضيحها،

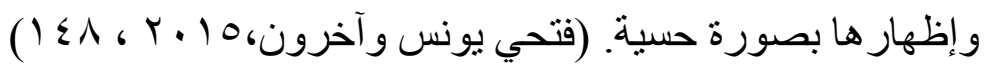

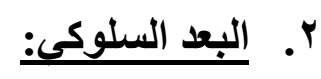

بتضمن الجانب المهاري تكوين العادات الحسنة المرغوبة لدى المتعلمين، وتطبيقها سلوكيا في حياتهم، وتنشئة المتعلمين على معرفة أحكام الدين، و إقامة الشعائر الدينية، وترجمة القيم والأخلاق الإسلامية إلى سلوك يتفق والدين الإسلامي، وتتمية قدرات المتعلمين على القيام بدو هم وواجبهم في عمارة الأرض، و استثمار خيراتها، و القيام بأعباء

$$
\text { الاستخلاف في الأرض. }
$$

\section{ومن معايير البعد السلوكي ما يلي}

تنمية الروح الدينية لدى التلاميذ، ومساعدتهم على أن يتخلقو ابخلق الإسلام، وأن

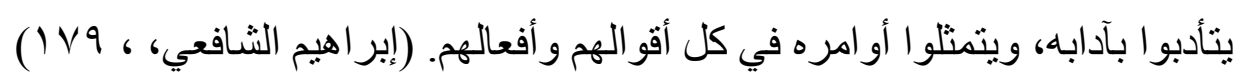

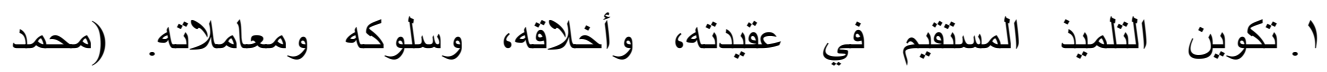

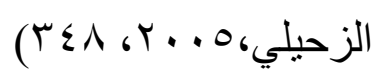

r. تكوين التلميذ الملتزم بأداء فرائض الله تعالى، والتوجه الخالص إليه بكل أنواع

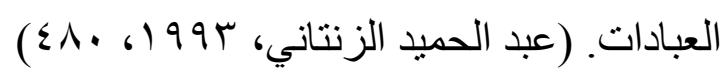

$$
\begin{aligned}
& \text { ومن مؤشرات هذا المعيار ما يلي: }
\end{aligned}
$$




\section{الجمعية المصرية للقر اءة والمعرفة عضو الجمعية الدولية للمعرفة ILA}

r. تكوين قاعدة راسخة من المعتقات المعرفية والوجدانية، تشكل الدافع الذي يحفز التلميذ لأنماط السلوك الديني القويم في الأقو ال والأفعال. (ماجد الجلاد، ب ا • Y، VO)

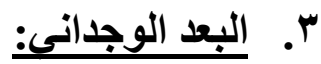

يتضمن البعد الوجداني تنمية حس المر اقبة الذاتية للمتعلمين، وأن الله عز وجل مطلع

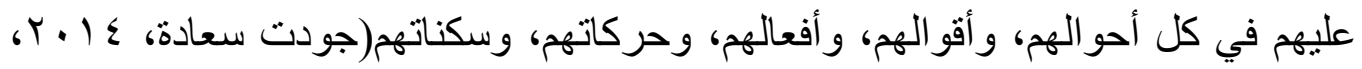
1/(ب)، وتنمية القيم الدينية المرغوب فيها لدى المتعلمين، والتي يقرها الدين الإسلامي، وكذلك الاقتداء بسيرة الرسول صلى الله عليه وسلم، وسير الأئمة العظام من المسلمين، أدبا، و علما، وخلقا، وسلوكا، وترسيخ عقيدة التوحيد في نفوس المتعلمين، بما يتناسب مع مظاهر النمو المختلفة لشخصياتهم، و اشباع العواطف الإنسانية النبيلة لدى المتعلمين، كعاطفة التدين، والولاء، والانتماء، وتهذيب أخلاق المتعلمين، بحيث يتخلقو الأخلاق الحميدة، وضبط سلوكهم بما يتفق و الدين الإسلامي. (إبر اهيم عطا، ه . . T، (T)

\section{ومن معايير البعد الوجداني ما يلي:}

ا ـ استشعار مر اقبة الله تعالى، وسعة علمه، وإحاطته بكل صغيرة وكبيرة، وأنه مطلع

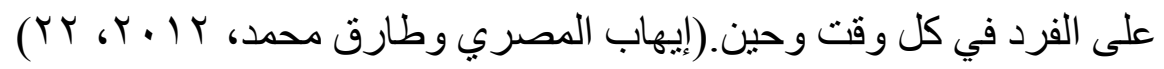
r. حب التلاميذ للدين الإسلامي، والاعتزاز به عن عاطفة راسخة ووجدان عميق.

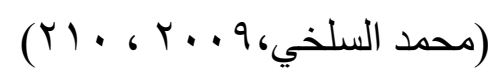

r. إثارة العواطف، وتحريك المشاعر التي تولد الطاقة والمقدرة المؤثرة بدورها على

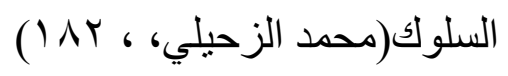

غرس القيم والاتجاهات المتضمنة في الأحكام الشرعية في نفوس التلاميذ، بحيث تخلق لاى التلاميذ حب هذه التشريعات و الميل إلى ممارستها. (محمد السلخي، 9 . . Y ، OV) 


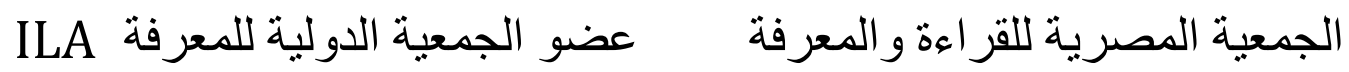

\section{بناء أدوات البحث ومواده وإجراءات تطبيقها:}

$$
\text { أولا: منهج البحث:استخدم في البحث: }
$$

- المنهج الوصفي: والذي استخدم في استقر اء البحوث و الدراسات السابقة، وفي تحديد أبعاد الوعي الديني المناسبة لتلاميذ الصف الخامس الابتدائي، وفي وصف الظاهرة

$$
\text { ثانيًا: أدوات البحث ومواده: }
$$$$
\text { فيما يأتي عرض تفصيلي لخطوات إعداد أدوات البحث ومو اده: }
$$

أـ قائمة معايير الوعي الايني اللازمة لتلاميذ الصف الخامس الابتدائي:

تم الاعتماد على معايير الوعي الديني للصف الخامس الابتدائي المعتمدة في دولة الكويت، وكما هي مقرة في مصفوفة وثيقة المنهج الصادرة عن وزارة التربية والتعليم لعام

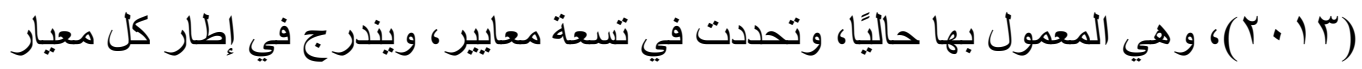
ثلاثة أبعاد، وبذا يكون عدد أبعاد الوعي الديني(YV) سبعة و عشرين بُعدًا.

بـ استمارة تقويم محتوى كتاب التربية الإسلامية للصف الخامس الابتدائي في دولة الكويت في ضوء أبعاد الوعي الديني وتطبيقها.

لإعداد استمارة تقويم محتوى كتاب التربية الإسلامية للصف الخامس الابتدائي في دولة الكويت؛ تمَّت الإجر اءات الآتية : 1 - تحديد الهدف من استمارة تحليل المحتوى. r- مصادر إعداد استمارة تحليل المحتوى. r- تحديد فئات التحليل. ع - تحديد وحدة تحليل المحتوى. 0ـ صدق تحليل المحتوى. 


\section{ILA الجمعية المصرية للقر اءة والمعرفة عضو الجمعية الدولية للمعرفة}

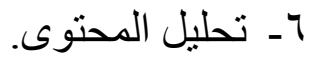

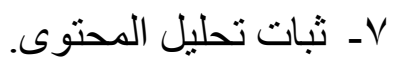 \\ وفيما يأتي تفصيل لذلك: \\ ا. تحديا الهذف من تصميم استمارة تحليل المحتوى:}

تمثل الهدف من تصميم استمارة تحليل المحتوى إلى التحقق من مدى تو افر أبعاد الوعي الديني في محتوى كتابالتربية الإسلامية للصف الخامس الابتدائي في دولة الكويت.

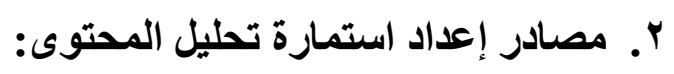

تمَّ إعداد استمارة تحليل المحتوى بعد الرجوع إلى المصادر الآتية:

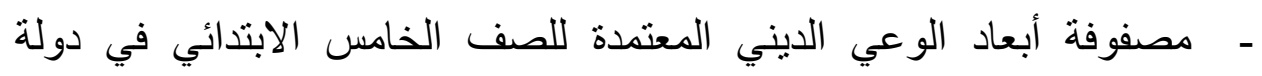
الكويت، المبينة في مصفوفة وثيقة منهج التربية الإسلامية للعام (س ( ب م)، و التي ما يز ال معدو لا بها حاليًا. - الأدب النظري و الدرسات ذات الصلة بموضوع البحث الحالي.

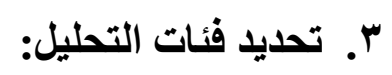

تمثل فئات التحليل العناصر الرئيسة والثانوية التي يتم وضع وحدات التحليل فيها، وفئات التحليل المستخدمة في البحث الحالي هي أبعاد الوعي الديني، حيث قامت الباحثة بتحويل هذه الأبعاد إلى فئات تحليل. ع. تحديد وحدة التحليل: بقتصر تحليل المحتوى في هذا البحث على وصف الظاهرة دون تأويلها؛ وسيعتمد على رصد التكرارات المنظمة لوحدة التحليل، واعتمد البحث' الحالي الفقرة كوحدة تحليل؛ كونها تتناسب مع فئات التحليل المعتمدة في هذا البحث، و المتمثلة بأبعاد الوعي الديني. •. استمارة التحليل في صورتها الأولية: 


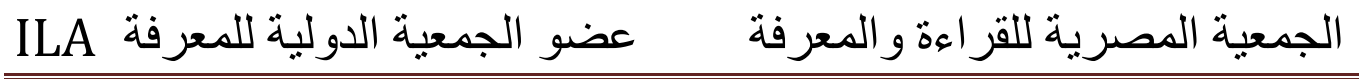

تكونت استمارة تحليل المحتوى في صورتها الأولية من (Y^)بعدًا من أبعاد الوعي الديني،

$$
\text { تندر ج في إطار (9)معايير. }
$$

7. تحليل المحتوى: قامت الباحثة بتحديد مجتمع التحليل، والمتمثل في منهج التربية

الإسلامية للصف الخامس الابتدائي في دولة الكويت، ويشمل على كتابين( الجزء

$$
\text { الأول و الجزء الثاني)، وبيانتها في الجدول الآتي: }
$$

\section{جدول(1)}

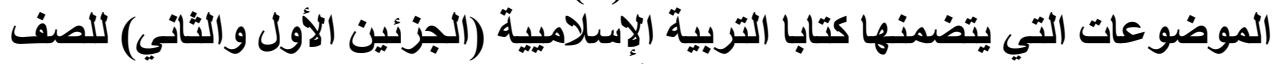

\begin{tabular}{|c|c|c|}
\hline \multicolumn{2}{|l|}{ الدروس } & \multirow{2}{*}{ الفرحدة أو } \\
\hline الجزء الثاني (•^)صفحة & الجزء الأول(^^)صفحة & \\
\hline الحساب & البعث بعد الموت & \multirow{3}{*}{ 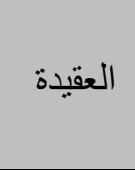 } \\
\hline الجنة & الحشر & \\
\hline النار & الشفاعة & \\
\hline الكتب السماوية توافق القرآن الكريم & تعريف بالقرآن الكريم & \multirow{3}{*}{ القرآن } \\
\hline نزول السكينة وملائكة الرحمة تكريمًا لقارئ القرآن & أول ما نزل من القرآن الكريم & \\
\hline بلاغة القرآن يشهر بها الأعداء & فضائل بعض سور القرآن الكريم & \\
\hline فضل الصبر على الأذى & فضل ذكر الله تعالّى & \multirow{3}{*}{ الشريف } \\
\hline فضل الصلاة على الرسول صلى الله عليه وسلم & كنز من كنوز الجنة & \\
\hline فضل صيام التطوع & لكل داء دواء & \\
\hline غزوة أحل & هجرة المسلمين من مكة إلى المدينة & \multirow{3}{*}{ النبوية } \\
\hline غزوة الخندق & المؤاخاة بين المهاجرين والأنصار & \\
\hline فتح مكة & 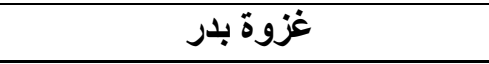 & \\
\hline صفة العمرة & فضل الحج & \multirow{3}{*}{ 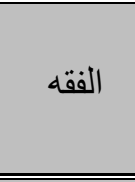 } \\
\hline سنن الإحرام ومحضوراته & شروط الحج وأركانه & \\
\hline أعمال الحج & مواقيت الحج وأنواعه & \\
\hline المحافظة على المال والاعتدال في افنفاق & الأخوة الإسلامية & \multirow{3}{*}{ التهذيب } \\
\hline أداء كل عمل في وقته و علدم تأجيله & اختيار الصديق & \\
\hline آداب النصيحة & آداب الطريق & \\
\hline 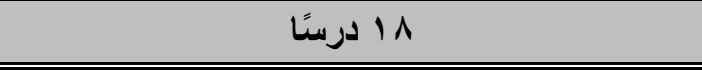 & 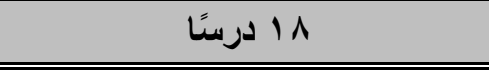 & المجموع \\
\hline
\end{tabular}

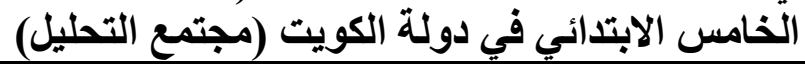




\section{ILA الجمعية المصرية للقراءة والمعرفة عضو الجمعية الدولية للمعرفة}

يتضح من الجدول أنَّ عينة التحليل تتكون من (r ( ) وحدة أو فرعًا، بواقع (†) وحدات أو

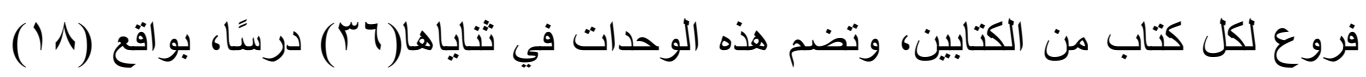

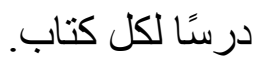

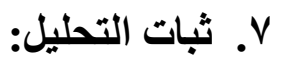

بعد التأكد من صدق استمارة تحليل المحتوى، قامت الباحثنة بتحليل محتوى كتابي

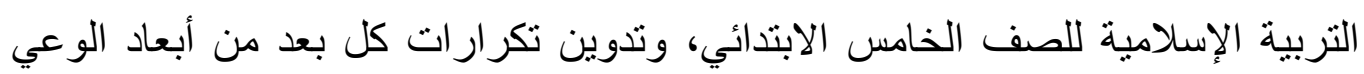

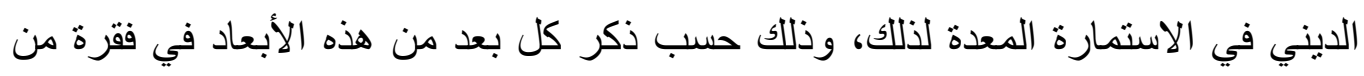

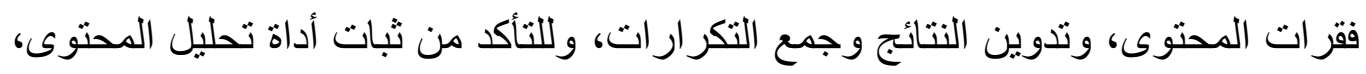
فقد نمَّ التحقق من ذللك بطر يقتين، و هما كما يأتي:

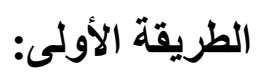

طلبت الباحثة من باحث آخر تحليل محتوى الكتابين، وبعد موافقة الباحث الآخر، تمّ شرح إجر اءات التحليل، وكيفية احتساب التكرار ات من الفقرات، ومن هذه الإجراءات: - فهم مكونات استمارة التحليل الخاصة بكل كتاب على حدة. - مقر اءة الدروس قراءة متأنية، وفحص فقر اتها.

- رصد وحدات التحليل المتو افرة في المحتوى، حيث تمثل كل فقرة وحدة تحليل في حال تو افر البعد الديني فيها، و إعطاء تكر ار واحد لكل فقرة. - - تسجيل أية ملحوظات يمكن ملاحظتها في أثناء التحليل. وبعد التأكد من إتقانه للتحليل، وفهمه لإجراءاته، قام المحلل الآخر بتحليل المحتوى وتسجيل النتائج، ومن ثم قام الباحث بمقارنة نتائج تحليله للمحتوى مع نتائج تحليل المحلل الآخر لنفس المحتوى، ولكل كتاب على حدة، وذلك عن طريق حساب تكرارات ظهور وحدات التحليل، ومقارنة التحليلين من حيث الاتفاق والاختلاف لكل درس ولك 


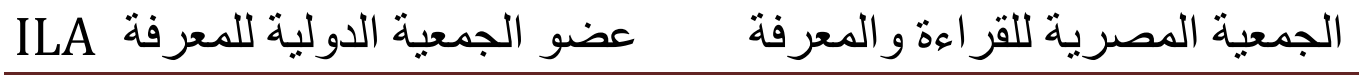

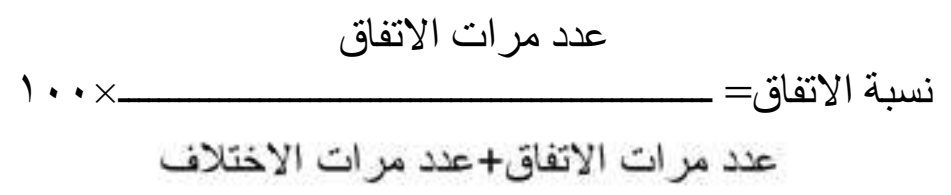

على حدة، ثم حساب مجموع مرات الاتفاق والاختلاف لكل كتاب على حدة، ثّم حساب مجموع مر ات الاتفاق و الاختلاف لجميع الدروس في الكتابين بشكل عام، ونمّ إيجاد معامل الاتفاق باستخدام معادلة هولستي الآتية:

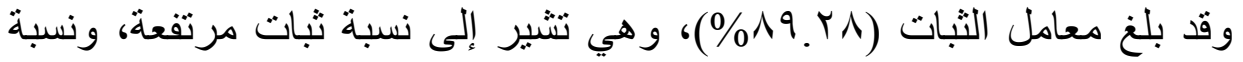
اتفاق عالية، وتقدم طمأنينة لصلاحية تطبيق استمارة التحليل لتحليل محتوى كتابي التربية الإسلامية للصف الخامس الابتدائي في دولة الكويت. الطريقة الثانية: - مئة

القيام بإعادة التحليل: حيث قامت الباحثة بتحليل محتوى منهج التربية الإسلامية للصف الخامس في دولة الكويت (الكتابين الأول والثاني) كما تُّ ذكره سابقًا، ورصد التكرارات، ومن ثمَّ قامت الباحثة بإعادة التحليل بعد مضي عشرين يومًا من التحليل الأول، ونتّ تطبيق معادلة هولستي السابق ذكر ها لمعرفة الثبات.

وقد بلغ معامل الثبات الكلي (1^.؟9\%)، وهي نسبة ثبات مرتفعة، تعطي التحليل قيمة في الاعتماد على نتائجه. 1- إجراءات التحليل: تمـت عمليـة تحليل محتوي كتـاب التربيـة الإسلامية للصف الخامس الابتدائي باسـتخدام أسلوب تحليل المحتوى وفقًا للإجر اءات الآتية: ا ـ قـر اعة كل موضـوع مـن موضـو عات كتـاب التربيـة للصف الخامس الابتدائي قر اءة فاحصة. r- استخر اج ما يحتويه مضمون كل موضوع من أبعاد الوعي الديني بشكل صريح أو $\varepsilon r$. 


\section{ILA الجمعية المصرية للقر اءة والمعرفة عضو الجمعية الدولية للمعرفة}

rـ تحديد عدد مر ات تناول محتوى كل موضوع لأبعاد الوعي الديني. عـ تسجيل نتائج تحليل كتابي التربية الإسـلامية للصف الخامس الابتدائي في الجداول الخاصة و التفصيلية المعدة مسبقًا لكل كتاب في استمارة التحليل الخاصة، و الموضح فيها كل فرع من فروع الكتاب الستة، وكذلك لكل موضوع من موضوعات كل فرع من هذه

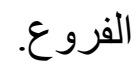

هـ حساب تكرار كل بعد من أبعاد الوعي الديني في كل كتاب على حدة، وحساب نسبة تكر ار كل بعد منها مقارنة بغيره من الأبعاد. T- جمع تكرارات هذه الأبعاد في الكتابين، حساب النسبة المئوية لكل بعد منها، وذلك تمهيدًا لتحليل هذه النتائج وتفسير ها. وبذلك تكون النتائج جاهزة للتحليل والتفسير، وهو ما سيتم توضيحه في الجزء الآتي من البحث. المعالجة الإحصائية: استخدم البحث التكرار ات و النسب المئوية لتحقيق أهدافه.

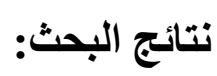

بالنسبة للسؤال الأول ونصه: ما أبعاد الوعي الديني اللازمة لتلاميذ الصف الخامس الابتدائي في دولة الكويت؟ لوابه وللإجابة عن هذا السؤال فقد نمَّ اعتماد أبعاد الوعي الديني التي تضمنتها مصفوفة معايير الوعي الديني ومؤشراته المعتمدة للصف الخامس الابتدائي في دولة الكويت، المبينة في وثيقة منهج التربية الإسلامية للعام (T ا ـ rم)، و التي ما يز ال معدو لا بها حاليًا، و هذه الأبعاد هي: ا ب. يذكر فضائل بعض السور من الأدلة الثرعية. r. . يمنح المحتوى فرص استتاج مر احل اليوم الأخر من الأدلة الثر عية. r. يلخص فضائل بعض سور القرآن الكريح. ع. يعرض المحتوى أثر القرآن الكريم في سيرة الصحابة الكر ام و التابعين. हा 


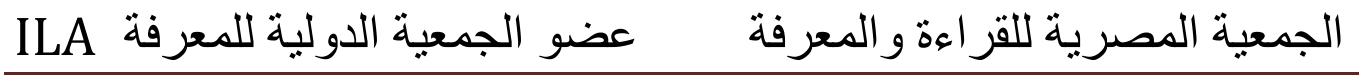

○. يعرض بعض مو اقف الصحابة من خلال قصص من السيرة النبوية. T. يعرض المحتوى أحداث السيرة النبوية للرسول في صورة خر ائط ذهنية. V. يستخدم لغة بسيطة للتعبير عن الدروس و العبر من سيرة الرسول. ^. يوضح دور التخطيط في تحقيق الأهداف من خلال هجرة الرسول. 9 9. يعرض أنتطة سلوكية متو افقة مع القيم و السلوكيات الإسلامية. • 1. يعرض أثر الإيمان من خلال صور لبعض العبادات والأخلاقيات الإسلامية. 11 1. يتضمن إصدار أحكام على بعض السلوكيات من واقع الحياة اليومية. r I . يعبر عن جمال الجنة ونعيمها مستثهـا بالثو اهد الثر عية.

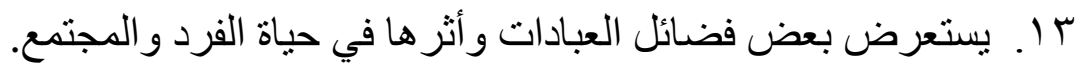
ـ ا. . يقدم عرضًا لمناسك الحج وشعائره في شكل مخطط أو خريطة ذهنية. 10. يتوافر في المحتوى ما يشير إلى أثر الاحتفالات الأعياد والمناسبات في إدخال

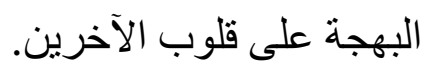

17 ا و يتضمن أنشطة يتطلب القيام بها إسهام التلميذ مع أقرانه. IV يوفر المحتوى مو اقف تثجع على التعاون مع جماعات الأنثطة الدينية . 11 ا. يقام المحتوى عرضنًا لكيفية مساعدة المنكو بين في الكو ارث الطبيعية. 9 19. يعرض حادثة المؤاخاة بين المهاجرين و الأنصار.

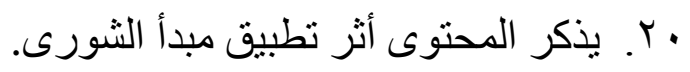

ا r. يعرض سير المعارك الإسلامية و التأكيد على أخلاقيات المسلمين فيها. r r. . يذكر المحتوى أثر التعاون بين الناس.

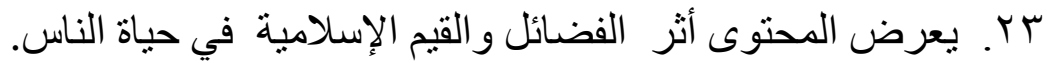
צ Y. يقدم المحتوى عرضًا لسيرة إحدى الثخصيات الوطنية ونضالاته.

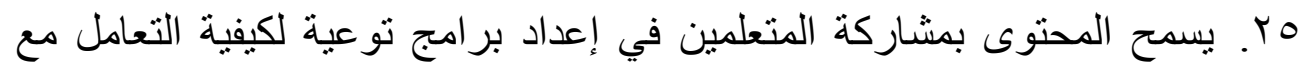
ذوي الاحتياجات الخاصة. 


\section{ILA الجمعية المصرية للقر اءة والمعرفة عضو الجمعية الدولية للمعرفة}

צr. يعرض المحتوى أهمية الاقتداء بالرسول " صلى الله عليه وسلم." VV يذكر المحتوى أهية الاستفادة والاعتزاز بسيرة الرسول وسيرة الصحابة

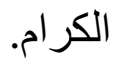

^ץ. يتيح المحتوى مشار كة المتعلمين في عرض مو اقف من سيرة الصحابة الكر ام. بالنسبة للسؤال الثاني ونصه:ما مدى توافر أبعاد الوعي الايني في محتوى كتابي التربية الإسلامية للصف الخامس الابتدائي (الجزئين الأول والثاني) في دولة الكويت؟ وللإجابة عن هذا السؤال فقد تنَّ القيام بتحليل محتوى كتابي التربية الإسلامية للصف الخامس في دولة الكويت بجزئيه(الأول و الثاني) في ضوء أبعاد الوعي الديني التي لائي

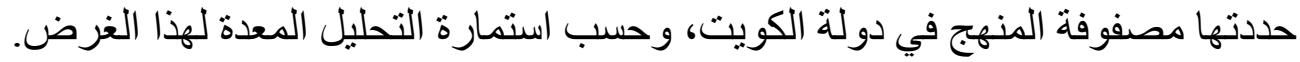
وستعرض الباحثة لهذه النتائج من العام إلى الخاص، وذلك كما يأتي:

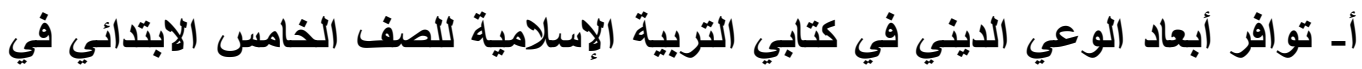
دولة الكويت بثكل إجمالي. تنَّ استخر اج تكرار ات أبعاد الوعي الديني، وتحديد النسبة المئوية لكل بعد من هذه الأبعاد،

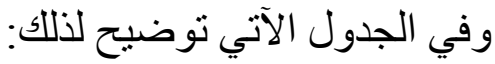




\section{ILA الجمعية المصرية للقر اءة والمعرفة عضو الجمعية الدولية للمعرفة}

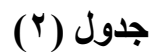

النسبة ومجموع تكرارات تو افر أبعاد الوعي الايني في محتوى كتاب التربية الإسلامية للصف الخامس في الجزئين الأول والثاني

\begin{tabular}{|c|c|c|c|}
\hline النسبة & التكر & ،عي الديني & المعايير \\
\hline$\%$ \%.q & 9 & يذكر فضائل بعض السور من الأدلة الثُرعية. & \multirow{3}{*}{ 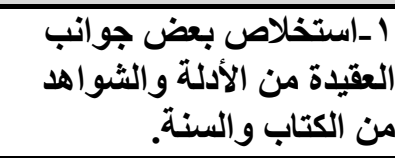 } \\
\hline$\%$ \%.・ & $\bar{v}$ & يمنح المحتوى فرص استنتاج مراحل اليوم الأخر من الأدلة الثر عية. & \\
\hline$\%$ \%.qr & 9 & يلخص فضائل بعض سور القرآن الكريم. & \\
\hline$\%$ \%.+ & $\mathrm{V}$ & يعرض المحتوى أثر القرآن الكريم في سيرة الصحابة الكرامو التابعين. & \multirow{3}{*}{ 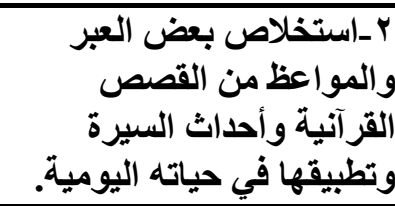 } \\
\hline$\% 9.7$. & rY & يعرض بعض مو اقف الصحابة من خلال قصص من السيرة النبوية. & \\
\hline$\%$ \%.१^ & 0 & يعروض خر ائط ذهنية. أحداث السبرة النبوية للرسول عليه الصلاة والسلام في & \\
\hline$\% 4.11$ & $1 \leq$ & يستخدم لغة بسيطة للتعبير عن الدروس و العبر من سيرة الرسول. & \multirow{3}{*}{ 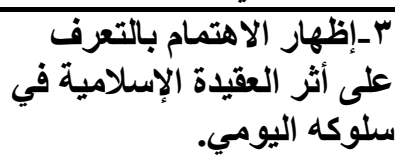 } \\
\hline$\%$ \%.Tr & 7 & يوضح دور التخطيط في تحقيق الأهداف من خلال هجرة الرسول. & \\
\hline$\% 1 . \mu 1$ & $r$ & يعرض أنشطة سلوكية منو افقة مع القيم و السلوكيات الإسلامية. & \\
\hline$\% 4.11$ & $1 \varepsilon$ & الإسرلامية. أثر الإيمان من خلال صور لبعض العبادات و الأخلاقيات & \multirow{3}{*}{ 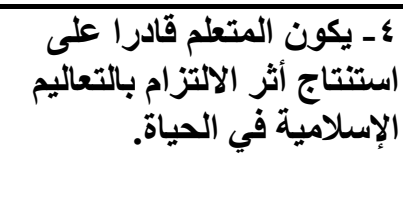 } \\
\hline$\%$ \%.rV & 1. & يتضعن إصدار أحكام على بعض السلوكيات من و اقع الحياة اليومية. & \\
\hline$\% 1 . V \varepsilon$ & $\varepsilon$ & يعبر عن جمال الجنة ونعيمها مستشهدا بالثو اهد الثر عية. & \\
\hline$\%$ \% Ir.Yr & rı & بستعرض بعض فضائل العبادات و أثر ها في حباة الفرد و المجتمع. & \multirow{3}{*}{ 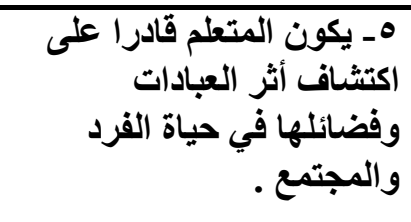 } \\
\hline$\%$ \%.Yr & 7 & يقدم عرضًا لمناسلك الحج وشعائره في شكل مخطط أو خريطة ذهنية. & \\
\hline صفر\% & - & إدخال البهجة في المحتى قلوب ما يشّر إلى أثر الاحتفالات الأعياد و المناسبات في & \\
\hline$\% \varepsilon . \wedge$. & 11 & يتضمن أنشطة يتطلب القيام بها إسهام التلميذ مع أقر انه. & \multirow{3}{*}{ 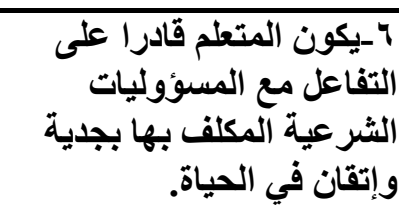 } \\
\hline صفر\% & - & يوفر المحتوى مو اقف تشجع على التعاون مع جماعات الأنشطة الدينية. & \\
\hline$\% \cdot . \wedge V$ & r & يقدم المحتوى عرضيًا لكيفية مساعدة المنكوبين في الكوارث الطبيعية. & \\
\hline$\% 1 . \vee \leqslant$ & $\varepsilon$ & يعرض حادثة المؤاخاة بين المهاجرين والأنصار & \multirow{3}{*}{ 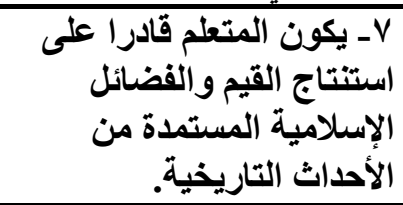 } \\
\hline$\% 1 . \vee \leqslant$ & $\varepsilon$ & يذكر المحتوى أثر تطبيق مبدأ الثورى. & \\
\hline$\% \% .+4$ & V & يعرض سير المعارك الإسلامية و التأكيد على أخلاقيات المسلمين فيها. & \\
\hline$\%$ \%!.Vะ & $\varepsilon$ & يذكر المحتوى أثُر التعاون بين الناس. & \multirow{4}{*}{ 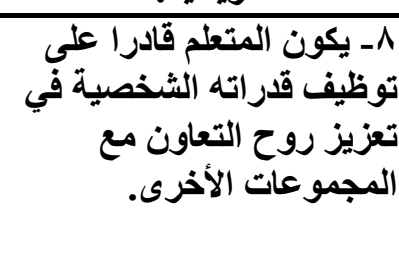 } \\
\hline$\% 7.00$ & 10 & يعرض المحتوى أثر الفضائل و القيم الإسلامية في حياة الناس. & \\
\hline صفر\% & - & يقدم المحتوى عرضًا لسيرة إحدى الثخصيات الوطنية ونضالاته. & \\
\hline صفر\% & - & ذِوي الاحتياجات الخاصنة. المشتعلمين في إعداد بر امج تو عية لكيفية التعامل مع & \\
\hline
\end{tabular}




\section{ILA الجمعية المصرية للقر اءة والمعرفة عضو الجمعية الدولية للمعرفة}

\begin{tabular}{|c|c|c|c|}
\hline$\%$ & $\Lambda$ & يعرض المحتوى أهمية الاقتداء بالرسول " صلى الله عليه وسلم". & 9 - يكون المتعلم قادرا \\
\hline$\% 9.99$ & 17 & وسلكر المحتوى أهمية الاستفادة و الاعتز از بسيرة الرسول " صلى الله عليه & في ممارسـاته وسلوكياته مئ ، وصحابته \\
\hline$\% 7.11$ & $1 \varepsilon$ & يتيح المحتوى مشاركة المتعلمين في عرض مو اقف من سبرة الصحابة. & 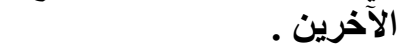 \\
\hline$\% 1 \ldots$ & rrq & 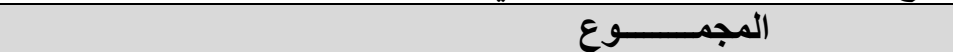 & \\
\hline
\end{tabular}

يتضح من خلال الجدول أنَّ مجموع التكرار في الكتابين قد بلغ (Y r ب) تكرارًا في كتابي التربية الإسلامية لجميع أبعاد الوعي الديني اللازمة لتلامبذ الصف الخامس الابتدائي في دولة الكويت، ويتضح من خلال الجدول ما يأتي: - أكثر أبعاد الوعي الديني تكرارًا كانت على التوالي، هي: (بستعرض بعض فضائل

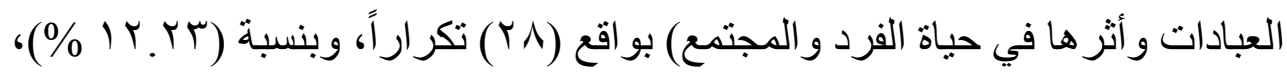
يليه (يعرض بعض مواقف الصحابة من خلال قصص من السيرة النبوية)، بواقع(Y)تكرارًا وبنسبة (.7.9 \%)، بليه (بذكر المحتوى أهمية الاستفادة و الاعتزاز بسيرة الرسول " صلى الله عليه وسلم" وسيرة الصحابة الكرام) بواقع (7 ( ) تكرارًا وبنسبة (9.9 \% \%)، ثم يأتي بعدها (بعرض المحتوى أثر الفضائل و القيم الإسلامية في حياة الناس) بواقع (0 1) وبنسبة (00.7 \% \% ) تكرارًا ، و (يتيح المحتوى مثاركة المتعلمين في عرض مو اقف من سيرة الصحابة الكر ام)، و(بعرض أثر الإيمان من خلال صور لبعض العبادات و الأخلاقيات الإسلامية)، و (يستخدم لغة بسيطة للتعبير عن الدروس والعبر من سيرة الرسول) بواقع (ع ا)تكرارًا وبنسبة

$$
.(\% 7.11)
$$

- أقل أبعاد الوعي الديني تكرارًا كانت: (يقدم المحتوى عرضًا لكيفية مساعدة المنكوبين في الكوارث الطبيعية) بواقع (Y) وبنسبة(NV. • \%)، و(يعرض أنشطة سلوكية

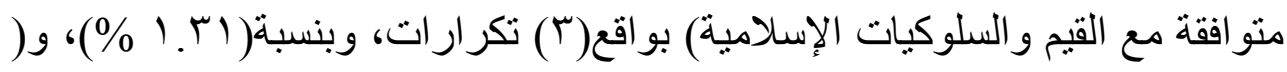
يذكر المحتوى أثر تطبيق مبدأ الثورى) و(يعرض حادثة المؤاخاة بين المهاجرين 


\section{الجمعية المصرية للقر اءة والمعرفة عضو الجمعية الدولية للمعرفة}

والأنصار)، و(يذكر المتوى أثر التعاون بين الناس) و(يعبر عن جمال الجنة

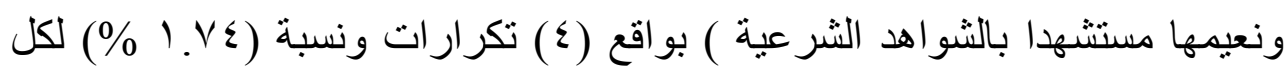
منها، ويأتي البعد(يعرض المحتوى أحداث السيرة النبوية للرسول عليه الصلاة

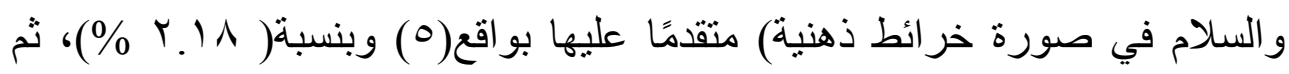
(يوضح دور التخطيط في تحقيق الأهداف من خلال هجرة الرسول) و(يقدم عرضًا لكناسك الحج وشعائره في شكل مخطط توضيحي أو خريطة ذهنية) بواقع(؟)

$$
\text { تكر ار ات وبنسبة (r. Y Y \%). }
$$

- ظهر من خلال التحليل للكتابين أنَّ هناك أربعة أبعاد لم تتو افر في الكتابين، وبالتالي فتكر ار كل منها كان(صفرًا)، و هذه الأبعاد على التوالي، ( يتوافر في المحتوى ما يثير إلى أثر الاحتفالات الأعياد والمناسبات في إدخال البهجة على قلوب الآخرين، ويوفر المحتوى مواقف نشجع على التعاون مع جماعات الأنشطة الدينية، ويقدم المحتوى عرضيًا لسيرة إحدى الشخصيات الوطنية ونضالاته، و يسمح المحتوى بمشاركة المتعلمين في إعداد برامج توعية لكيفية التعامل مع ذوي الاحتياجات

(الخاصة).

دـ عرض توافر أبعاد الوعي الديني في محتوى كتابي التربية الإسلامية في دولة الكويت للصف الخامس الابتدائي (الجزء الأول والجزء الثاني). سيتم عرض مدى تو افر أبعاد الوعي الديني في كتابي التربية الإسلامية (الجزء الأول ) و الثاني) المقررين على الصف الخامس الابتدائي في دولة الكويت: و الجدول الآتي يوضح ذلك: 


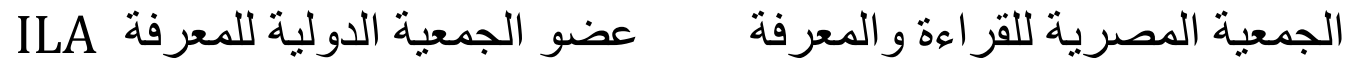

\section{جدول (ب) (ب) (ب)}

مجموع تكرارات توافر المؤشرات في محتوى كتاب التربية الإسلامية للصف الخامس في الجزئين الأول

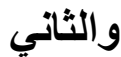

\begin{tabular}{|c|c|c|c|}
\hline التخاني & 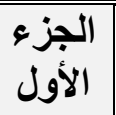 & 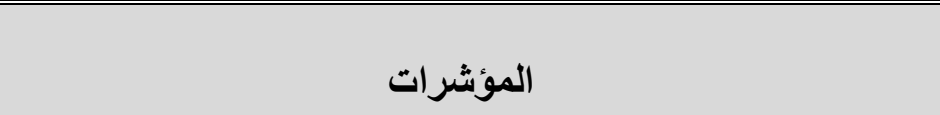 & المعاييز \\
\hline- & 9 & يذكر فضائل بعض السور من الأدلة الشر عية. & \multirow{3}{*}{ 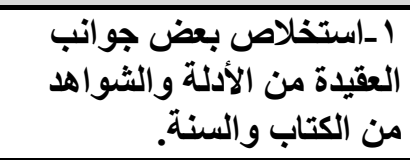 } \\
\hline 1 & 7 & يمنح المحتوى فرص استنتاج مر احل اليوم الأخر من الأدلة الثرعية. & \\
\hline- & 9 & يلخص فضائل بعض سور القرآن الكريح. & \\
\hline- & $\mathrm{V}$ & يعرض المحتوى أثر القر آن الكريم في سيرة الصحابة الكر ام و التابعين. & \multirow{3}{*}{ 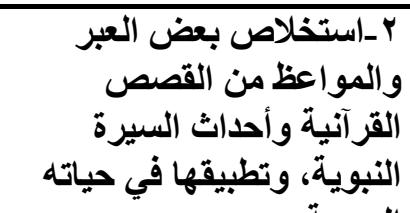 } \\
\hline 0 & IV & يعرض بعض مو اقف الصحابة من خلال قصص من السيرة النبوية. & \\
\hline$\varepsilon$ & 1 & يعرض المحتوى أحداث السيرة النبوية للرسول عليه الصلاة و السلام في & \\
\hline$\varepsilon$ & 1. & يستخدم لغة بسيطة للتعبير عن الدروس و العبر من سيرة الرسول. & \multirow{3}{*}{ 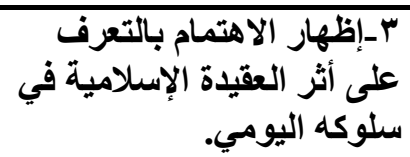 } \\
\hline$\varepsilon$ & r & يوضح دور التخطيط في تحقيق الأهداف من خلال هجرة الرسول. & \\
\hline- & $r$ & يعرض أنشطة سلوكية متو افقة مع القيم و السلوكيات الإسلامية. & \\
\hline r & 11 & الإسرلامية. & \multirow{3}{*}{ 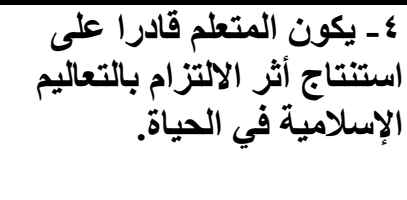 } \\
\hline 1 & 9 & يتضمن إصدار أحكام على بعض السلوكيات من واقع الحياة اليومية. & \\
\hline$\varepsilon$ & - & يعبر عن جمال الجنة ونعيمها مستشهذا بالشو اهد الثر عية. & \\
\hline 17 & Ir & يستعرض بعض فضائل العبادات و أثزر ها في حياة الفرد و المجتمع. & \multirow{3}{*}{ 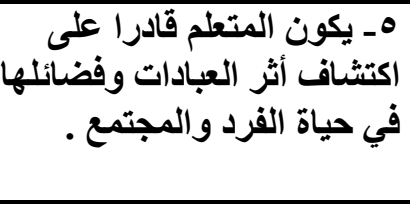 } \\
\hline$\bullet$ & 1 & يقدم عرضًا لمناسك الحج وشعائره في شكل مخطط أو خريطة ذهنية. & \\
\hline- & - & يتو إفر في المحتوى ما يشير إلى أثر الاحتفالات الأعياد و المناسبات في . & \\
\hline 7 & $\bullet$ & يتضمن أنشطة يتطلب القيام بها إسهام التلميذ مع أقر انه. & \multirow{3}{*}{ 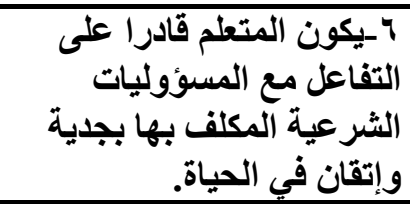 } \\
\hline- & - & يوفر المحتوى مواقف تشجع على التعاون مع جماعات الأنشطة الدينية. & \\
\hline- & r & يقدم المحتوى عرضيًا لكيفية مساعدة المنكوبين في الكوارث الطبيعية. & \\
\hline- & $\varepsilon$ & يعرض حادثة المؤ اخاة بين المهاجرين و الأنصار. & \multirow{3}{*}{ 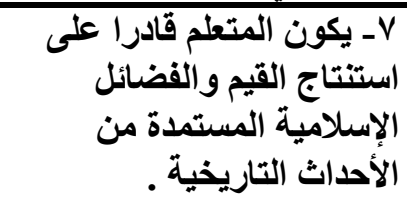 } \\
\hline r & r & يذكر المحتوى أثر تطبيق مبدأ الشورى. & \\
\hline$\bullet$ & r & يعرض سير المعارك الإسلامية و التأكيد على أخلاقيات المسلمين فيها. & \\
\hline$\overline{1}$ & $r$ & يذكر المحتوى أثر التعاون بين الناس. & \multirow{3}{*}{ 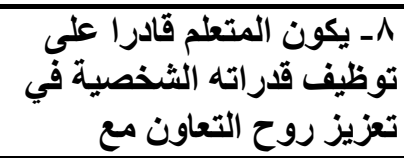 } \\
\hline$\varepsilon$ & 11 & يعرض المحتوى أثر الفضائل و القيم الإسلامية في حياة الناس. & \\
\hline- & - & يقدم المحتوى عرضًا لسيرة إحدى الشخصيات الوطنية ونضالاته. & \\
\hline
\end{tabular}




\section{ILA الجمعية المصرية للقر اءة والمعرفة عضو الجمعية الدولية للمعرفة}

\begin{tabular}{|c|c|c|c|}
\hline- & - & يسع ذوح المحتوى بمشّاركة المتعلمين في إعداد بر امج توعية لكيفية التعامل & المجموعات الأخرى. \\
\hline $\mathbf{0}$ & $\bar{\mu}$ & يعرض المحتوى أهمية الاقتداء بالرسول " صلى الله عليه وسلم". & \multirow{3}{*}{ 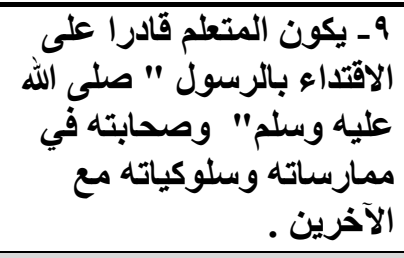 } \\
\hline$\Lambda$ & $\Lambda$ & يذكر المحتوى أهمية الاستفادة والاعتز از بسيرة الرسول " صلى الله وسيرة الصحرة & \\
\hline - & $1 \varepsilon$ & الكير ام. المحتوى مشاركة المتعلمين في عرض مو اقف من سيرة الصحابة & \\
\hline$\vee \wedge$ & 101 & \multicolumn{2}{|l|}{ 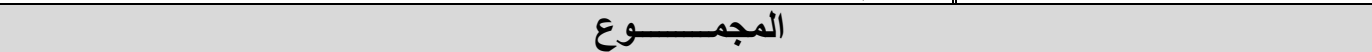 } \\
\hline
\end{tabular}

$$
\text { من خلال الجدول السابق يتضح الآتي: }
$$

- مجموع تكرارات تو افر أبعاد الوعي الديني في كتاب التربية الإسلامية (الجزء الأول)

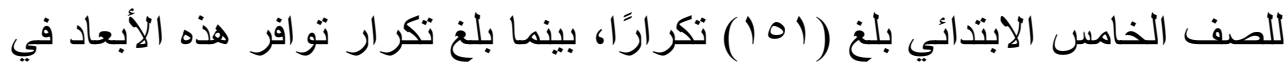

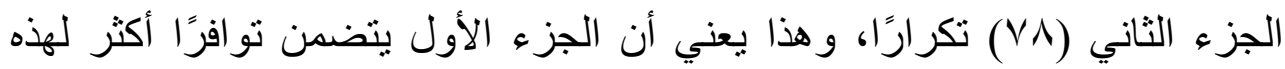
الأبعاد، تقارب ضعف ما يتوافر في الجزء الثاني، مما يستدعي إعادة النظر في محتوى الجزء الثاني، ومحاولة إحداث توازن في تضمين هذه الأبعاد في الجزئين. - عدد الأبعاد الني لم تحصل على أي تكرار في الجزء الأول بلغت (ع) أربعة أبعاد، بينما بلغ عدد الأبعاد التي لم تحصل على "أي تكرار أو تو افر في الجزء الثاني (1') أحد عشر بُعدًا من أبعاد الوعي الديني، وهذا يستدعي إعادة النظر في محتوى الجزئين، وفي تضمين هذه الأبعاد بشكل منو ازن في الكتابين.

تعليق عام على نتائج السؤال (الثاني) الخاص بتحليل محتوى كتابي التربية الإسلامية للصف الخامس الابتدائي في دولة الكويت: يمكن أنْ تستخلص الباحثة من هذه النتائج ما يأتي: - عدد توافر أبعاد الوعي الديني في كتاب التربية الإسلامية للصف الخامس الابتدائي في دولة الكويت (الجزء الأول) أعلى بكثير من تو افرها في (الجزء الثاني). -

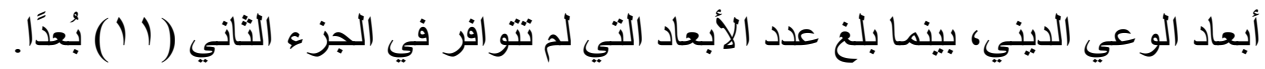
\& 


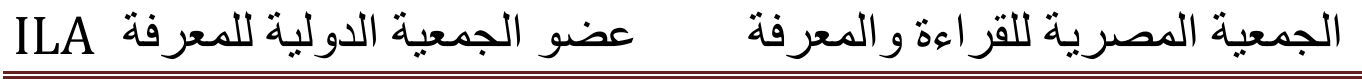

- هنالك الكثير من الأبعاد التي اتضح أنَّ عدد نو افرها أقل من المستوى المطلوب؛ وذللك يوجب مراعاة تضمين هذه الأبعاد في محتوى كتابي التربية الإسلامية للصف الخامس الابتدائي في دولة الكويت، وذلك عند إحداث أي تطوير للمنهج. - ضرورة مر اعاة التوازن في تضمين أبعاد الوعي الديني في الكتابين، بحيث يتقارب عدد تكر ار ها في الكتابين.

- مر اعاة التوازن في تضمين أبعاد الوعي الديني، بحيث يكون عدد تكرار ها متقاربًا. - الأبعاد التي أظهر التحليل عدم تو افرها أو قلة تو افرها بلغت (T I) بُعدًا، وهي على التوالي: يتو افر في المحتوى ما يشير إلى أثر الاحتفالات الأعياد و المناسبات في إدخال البهجة على قلوب الآخرين، ويوفر المحتوى مواقف تشجع على التعاون مع جماعات الأنشطة الدينية، ويقدم المحتوى عرضًا لسيرة إحدى الشخصيات الوطنية ونضالاته، و يسمح المحتوى بمشاركة المتعلمين في إعداد برامج توعية لكيفية التعامل مع ذوي الاحتياجات الخاصة، ويقدم المحتوى عرضنًا لكيفية مساعدة المنكوبين في الكوارث الطبيعية، ويعرض أنشطة سلوكية متوافقة مع القيم و السلوكيات الإسلامية، ويذكر المحتوى أثر تطبيق مبدأ الشورى، ويعرض حادثة المؤاخاة بين المهاجرين والأنصار ، ويذكر المحتوى أثر التعاون بين الناس، ويعبر عن جمال الجنة ونعيمها مستشهدا بالثواهد الثرعية، ويعرض المحتوى أحداث السيرة النبوية للرسول عليه الصلاة والسلام في صورة خر ائط ذهنية، ويوضح دور التخطيط في تحقيق الأهداف من خلال هجرة الرسول، ويقدم عرضًا لمناسك الحج وشعائره في شكل مخطط توضيحي أو خريطة ذهنية). - إجمالي عدد أبعاد الوعي الديني كما في مصفوفة وثيقة المنهج، والتي اعتدمت في تحليل الكتابين (YV) بُعدًا، وبلغ عدد الأبعاد التي أظهر التحليل عدم تو افرها أو قلة 


\section{ILA الجمعية المصرية للقر اءة والمعرفة عضو الجمعية الدولية للمعرفة}

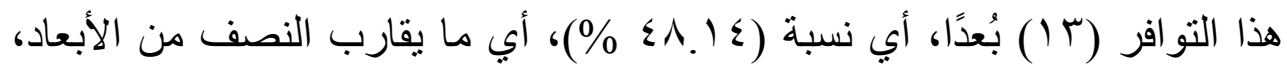
و هذا يوجب على مطوري المناهج مر اعاتها في أي تطوير لمناهج التربية الإسلامية.

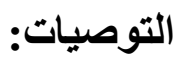

في ضوء نتائج البحث، فإنَّه يمكن تقديم التوصيات الآتية: ا ـ إعادة النظر في أبعاد الوعي الديني، ومر اجعتها، والاستفادة من معايير الوعي الديني المطبقة في الدول المختلفة، وبما يو اكب التطورات الحاصلة في ميدان التربية.

r. تحليل كتب التربية الإسلامية في مختلف المر احل و الصفوف في ضوء أبعاد الوعي الديني.

r. إعادة النظر في تضمين أبعاد الوعي الديني في مناهج التربية الإسلامية لصفوف المرحلة الابتدائية في دولة الكويت.

ع. . مر اعاة التوازن في تضمين أبعاد الوعي الديني في كتب التربية الإسلامية المقررة على المرحلة الابتدائية(الجزء الأول والثاني) في دولة الكويت.

○. إعادة النظر في مصفوفة وثيقة منهج التربية الإسلامية المعدول بها في وزارة التربية و التعليم في دولة الكويت. 7 7. تطوير مناهج التربية الإسلامية في دولة الكويت في ضوء أبعاد الوعي الديني. V. تطوير مناهج التربية الإسلامية للمرحلة الابتدائية في دولة الكويت؛ بما يجعلها تو اكب التطور ات في عالم التربية و التعليم و المستحدثات التكنولوجية. 


\section{الجمعية المصرية للقر اءة والمعرفة عضو الجمعية الدولية للمعرفة ILA}

^. . وضع آلية لتعريف معلمي التربية الإسلامية في دولة الكويت بأبعاد الوعي الديني

التي تتضمنها مصفوفة وثيقة منهج التربية الإسلامية؛ ليكونو ا على در اية بها،

ومحاولة تحقيقها وترسيخها في عقول التلاميذ.

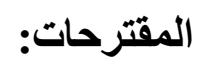

في ضوء نتائج البحث يمكن تقديم المقترحات الآتية:

ا. ـ تحليل كتب التربية الإسلامية للمرحلة الابتدائية في دولة الكويت في ضوء أبعاد

$$
\text { الوعي الديني. }
$$

r. تقويم كتب التربية الإسلامية للمرحلة الابتدائية في دولة الكويت في ضوء أبعاد

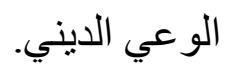

r. تطوير محتوى منهج التربية الإسلامية للمرحلة المتوسطة في دولة الكويت في

$$
\text { ضوء أبعاد الوعي الديني. }
$$




\section{ILA الجمعية المصرية للقر اءة والمعرفة عضو الجمعية الدولية للمعرفة}

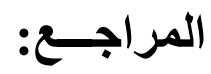

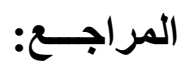

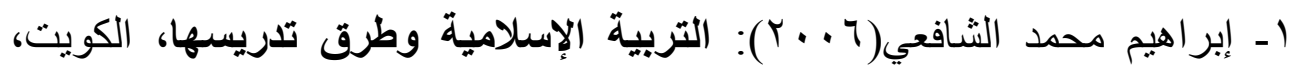
مكتبة الفلاح،الطبعة الر ابعة.

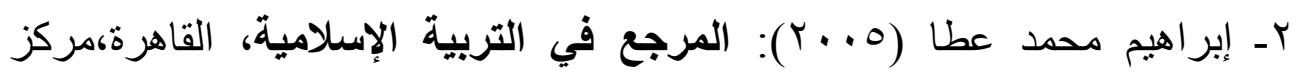

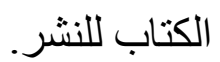

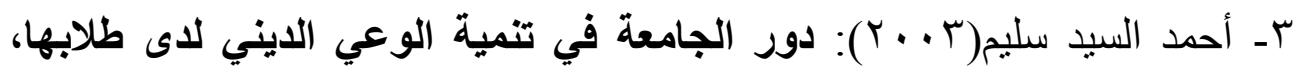
رسالة دكتور اه غير منشورة، جامعة أسيوط،مصر.

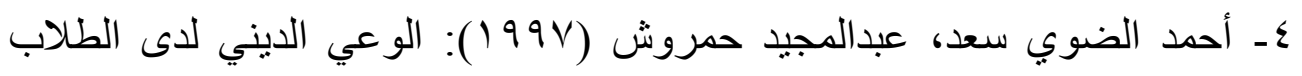

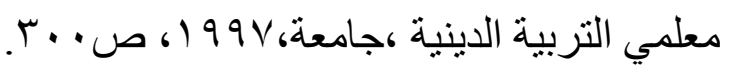

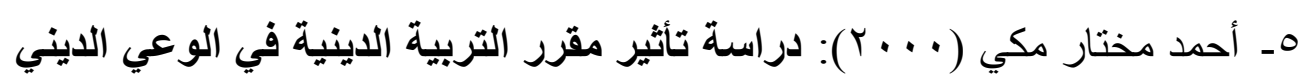

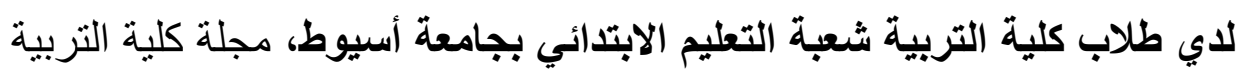

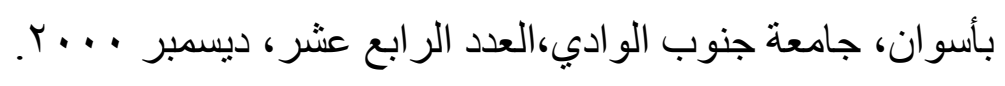

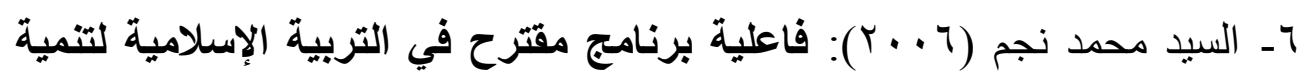
الوعي الايني لبعض القضايا المحلية والعالمية لاى طلاب المرحلة الثانوية،

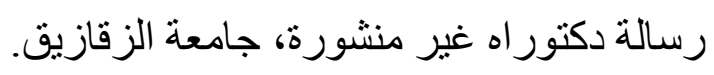

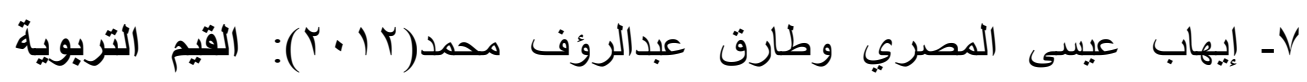
الأخلاقية، القاهرة،مؤسسة طيبة للنشر.

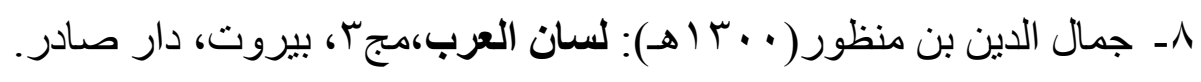

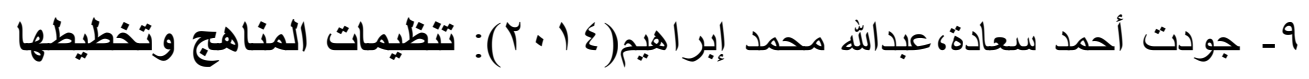

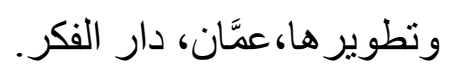




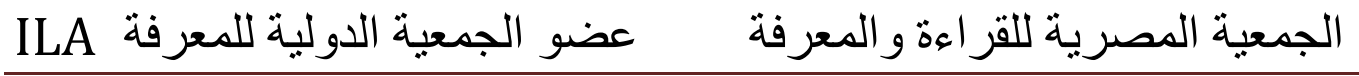

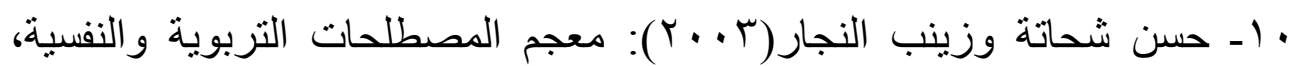
الدار المصرية اللبنانية، الطبعة الأولى. | 1 - حسن شحاتة(؟9 99 (): تعليم الدين الإسلامي بين النظرية والنطبيق، القاهرة، مكتبة الدار العربية للكتاب. ץ ا - خالد عبدالرحيم الكندري (10 1 ب): المناهج،الكويت، دار العلم. ץ ا ـ سلام سيد أحمد. تنمية الوعي العلمي لدى طلاب المرحلة الثانوية في دول الخليج العربية، الرياض، رسالة الخليج العربي، مكتب التربية العربي لدول الخليج، عء ع.

ع ا ـ سميرة قنديل، أحمد السيد، الحسنى ريحان، الاء أبورية (9 + . Y): فعالية برنامج إرشادي لتنمية المهار ات الإدارية في ظل الوعي الديني لدى ربات الأسر بمحافظة الدقهلية، المؤتمر السنوي ( الدولي الأول_العربي الرابع) الاعتماد الأكاديمي لمؤسسات وبرامج التعليم العالي النوعي في مصر والعالم العربي "الواقع

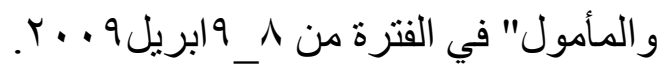

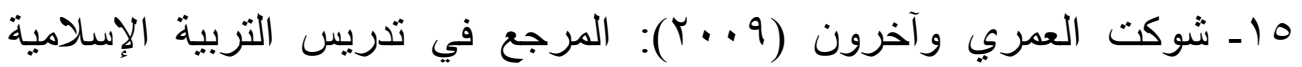

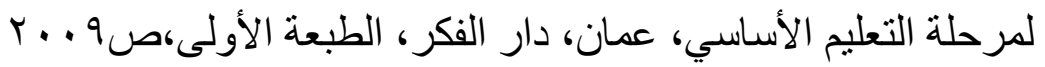

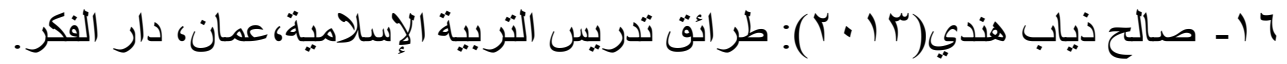

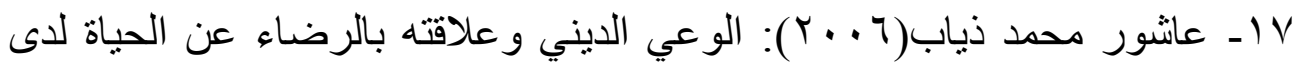
عينة من شباب الجامعة،جامعة المنيا، مجلة البحث في التربية وعلم النفس،

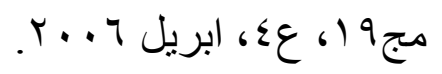

1 1 ـ عبدالتو اب عبداللاه عبدالتواب(9NV ( )): الوعي الديني لأى أطفال الحلقة الأولى من التعليم الأساسي في ضوء المستوى الاجتماعي الاقتصادي للأسرة "دراسة

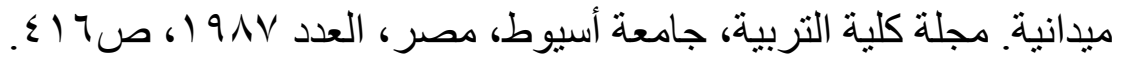




\section{الجمعية المصرية للقر اءة والمعرفة عضو الجمعية الدولية للمعرفة ILA}

9 1 ــ عبدالحميد الصيد الزنتاني(999 (1): أسس التربية الإسلامية في السنة النبوية،

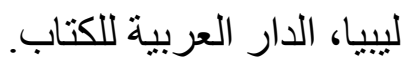

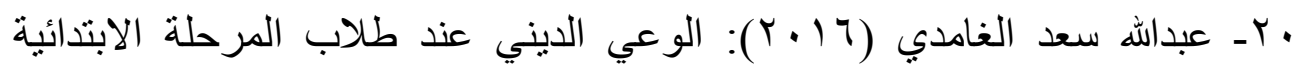
و علاقته ببعض متغيرات التنشئة الاجتماعية بمنطقة الباحة، رسالة دكتوراة غير التراني

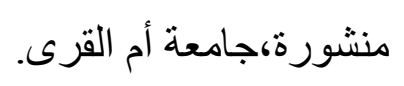

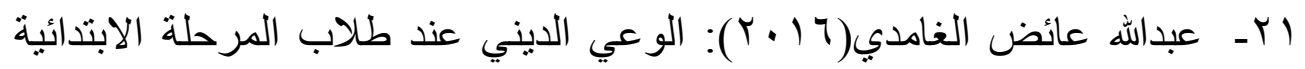
و علاقته ببعض متغير ات التنشئة الاجتماعية بمنطقة الباحة، رسالة دكتوراة غير الرئ

منشورة، جامعة أم القرى، المملكة العربية السعودية، كلية التربية.

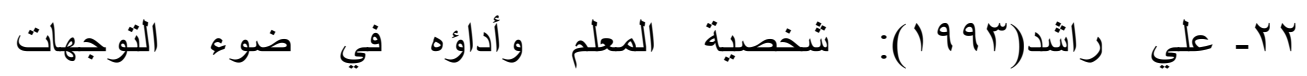
الإسلامية، القاهرة، دار الفكر العربي.

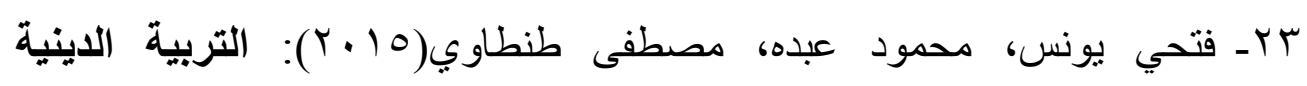
الإسلامية بين الأصالة والمعاصرة، القاهرة، مكتبة و هبه، الطبعة الأولى.

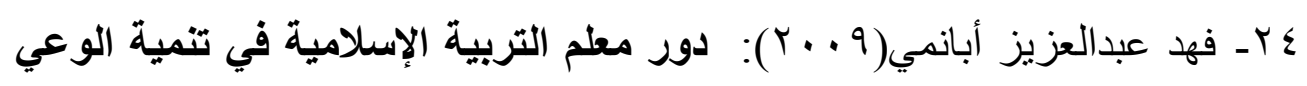

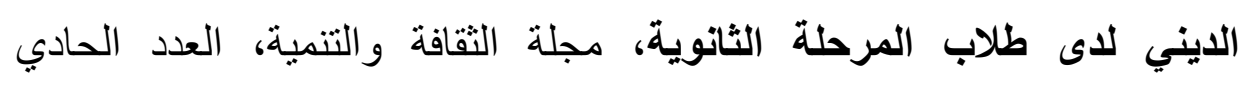

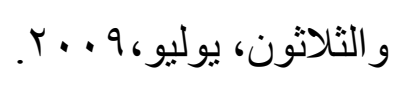

Or - مؤتمر "التعصب والتطرف الفكري"، كلية الثريعة والدراسات الإسلامية،

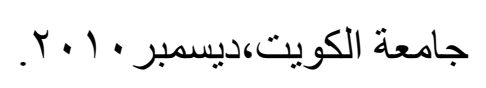

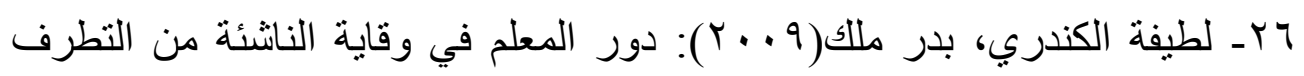

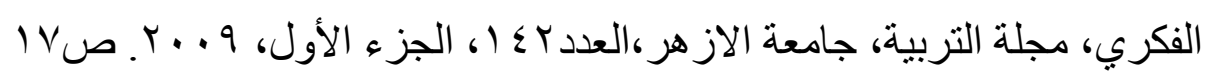

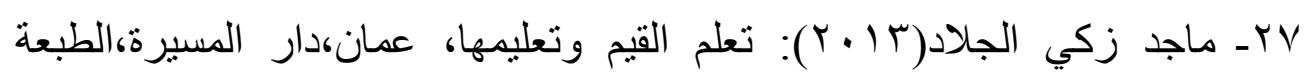
الر ابعة.

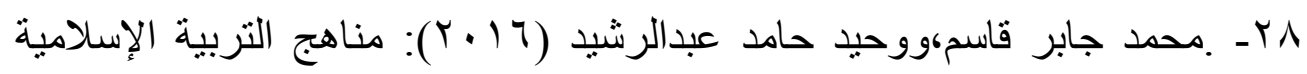
ومتطلبات تدريسها، القاهرة، الدار الدصرية اللبنانية. 


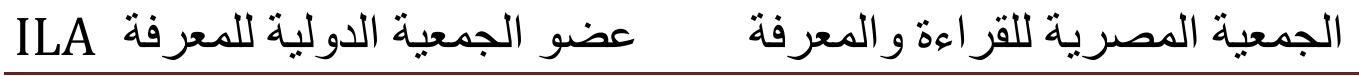

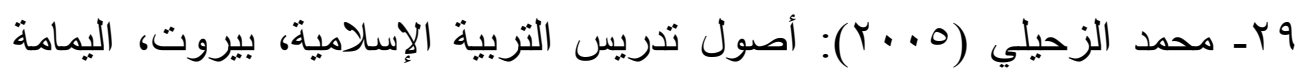

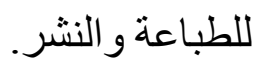

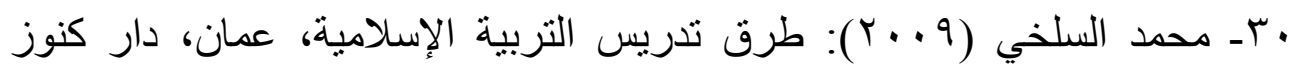

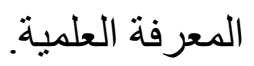

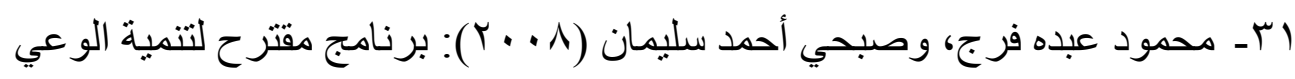
بالتعليم الاكتروني وتطبيقاته لدى شعبة التربية الإسلامية بكليات التربية، مجلة

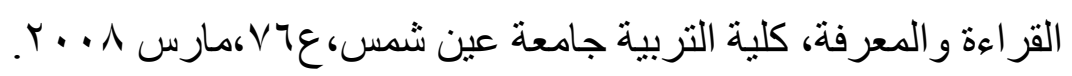

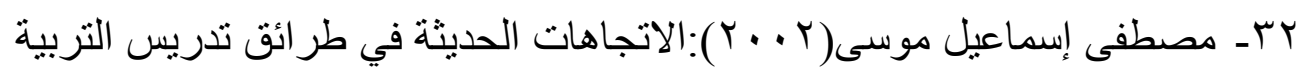
الدينية الإسلامية،الامار ات،دار الكتاب الجامعي. rr- مصطفى رجب سالم (1 . +ץ): تحليل كتب التربية الدينية الاسلامية بالمرحلة

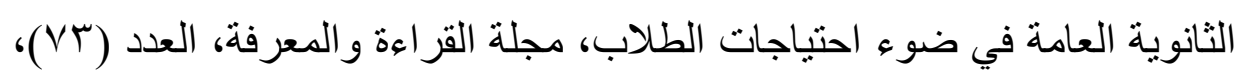

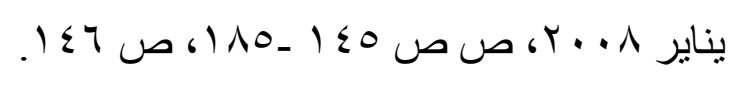

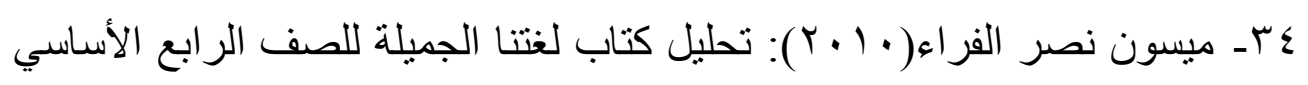

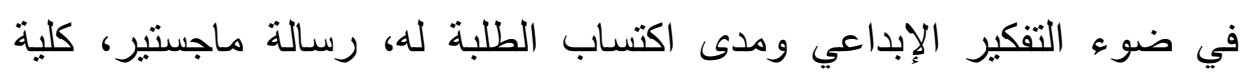

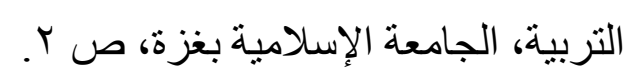

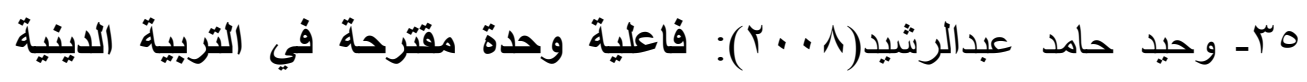

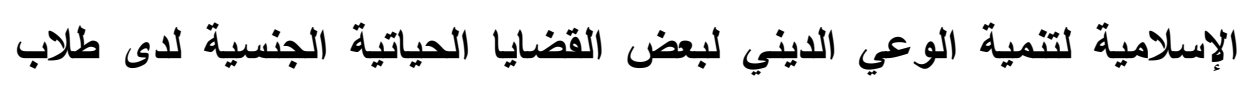

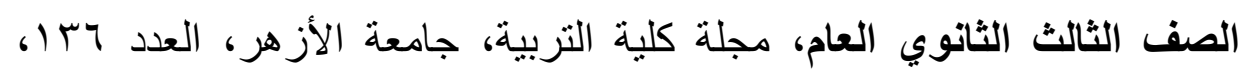

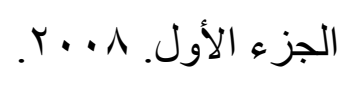

جr- وضحة علي السويدي(911 (1): منهج التربية الإسلامية في المرحلة الابتدائية بدولة قطر، الدوحة، دار الثقافة للنشر. TrV - هدى علي الثمري. طرق تدريس التربية الإسلامية، مرجع سابق. 


\section{الجمعية المصرية للقر اعة والمعرفة عضو الجمعية الدولية للمعرفة ILA}

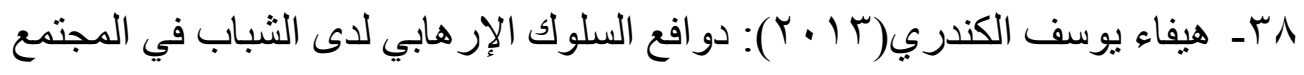

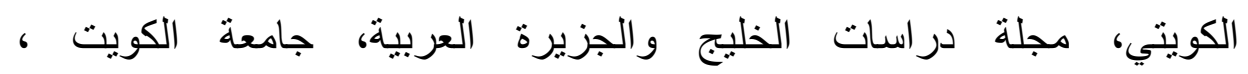

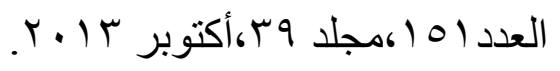

